\title{
Savaş ve Propaganda: 1683 Viyana Kuşatması Üzerine Bir Değerlendirme
}

\author{
Songül Çolak* - Metin Aydar** \\ $\ddot{O ̈ z}_{\mathbf{z}}$
}

Propaganda, insanları istenen şekilde düşünmeye ve davranmaya ikna etmek için tasarlanmış bir yöntemdir. Geçmişi, insanların birbirleriyle ilk iletişim kurmaya başladığı zamana dayanmaktadır. Bu doğrultuda propaganda, kişisel çıkarlara hizmet eden ve sık başvurulan bir yöntem olmuştur. Tarih boyunca insanlar, propaganda faaliyetlerinden çeşitli şekillerde yararlanmışlardır. Özellikle savaş zamanlarında etkin bir şekilde kullanılan propaganda faaliyetleri, bu süreçte insanları ikna etmek, cesaretlendirmek ve savaşı desteklemek konusunda önemli bir role hizmet etmiştir. $\mathrm{Bu}$ bağlamda, bir savaşın başlamasından bitmesine kadar uygulanan propaganda faaliyetleri, bu kavramla savaşın birbirinden ayrılmaz bir şekilde bağlantılı olduğunu göstermektedir.

Bu çalışma, XVII. yüzyılın son çeyreğinde ortaya çıkan, Türk ve Avrupa tarihinin en önemli siyasi hadiselerinden birisi olan 1683 Viyana Kuşatması'ndaki propaganda faaliyetlerine odaklanmaktadır. Sonuçları itibarıyla, gerek Osmanlı Devleti'ni gerekse Habsburg İmparatorluğu’yla birlikte diğer Batılı devletlerin geleceğini şekillendiren bu savaş, siyasi, sosyal ve iktisadi açıdan pek çok kez ele alınmıştır. Fakat savaşın öncesinden sonuna kadar gerçekleştirilen propaganda faaliyetleri pek ele alınmamıştır. $\mathrm{Bu}$ noktadan hareketle çalışma, her iki tarafin savaşın karar aşamasından sonuçlanmasına kadar geçen süreçte başvurdukları propaganda yöntemlerini ortaya koymaktadır.

Çalışmada, Sadrazam Merzifonlu Kara Mustafa Paşa'nın, çeşitli propaganda faaliyetleriyle devlet erkânını savaşa ikna etmek, ordunun moralini yüksek tutmak ve düşmanın maneviyatını kırmak gibi propaganda faaliyetlerine giriştiği görülmektedir.

* Prof. Dr., Samsun Üniversitesi, İktisadi, İdari ve Sosyal Bilimler Fakültesi, Tarih Bölümü, Samsun/TÜRKIYE, doggul70@gmail.com ORCID: 0000-0003-3800-2397 DOI: 10.37879/belleten.2020.1045

** Arş. Gör., Erzurum Teknik Üniversitesi, Edebiyat Fakültesi, Tarih Bölümü, Erzurum/TÜRKIYE, metin.aydar@erzurum.edu.tr ORCID: 0000-0002-6311-7527

Makale Gönderim Tarihi: 05.09.2019 - Makale Kabul Tarihi: 11.08.2020 
Onun propaganda faaliyetlerine karşılık Habsburg hükümeti, Hristiyan devletleri kendi safinda savaşa dâhil etmek, şehrin savunulmasında halkın ilgisini ve katılım düzeyini artırmak için çeşitli propaganda faaliyetlerine başvurmuştur.

Anahtar Kelimeler: Osmanlı İmparatorluğu, Habsburg İmparatorluğu, Viyana, Merzifonlu Kara Mustafa Paşa, Propaganda.

War and Propaganda: An Evaluation on the 1683 Vienna Siege

\begin{abstract}
Propaganda is a method designed to persuade people to think and act in the desired way. Its history dates back to when people first started communicating with each other. In this direction, propaganda has become a frequently used method that serves to personal interests. Throughout history, people have benefited from propaganda activities in various ways. Propaganda activities, especially used effectively in times of war, have served an important role in persuading, encouraging and supporting to the war in this process. In this context, the propaganda activities carried out from the beginning of a war to its end reveal that this concept and war are inextricably linked.

This study focuses on the propaganda activities in the 1683 Vienna Siege, which emerged in the last quarter of the XVII ${ }^{\text {th }}$ century and was one of the most important political events in Turkish and European history. This war, which shaped the future of both the Ottoman Empire and the Habsburg Empire, as well as other Western states, has been discussed many times in terms of political, social and economic terms. However, the propaganda activities carried out from the beginning to the end of the war have not been discussed much. From this point of view, the study reveals the propaganda methods used by both sides in the process from the decision-making to war until its conclusion.

In the study, it is seen that the Grand Vizier Kara Mustafa Pasha of Merzifon engaged in propaganda activities such as convincing the state officials to war, keeping the morale of the army high and breaking the spirituality of the enemy with various propaganda activities. In response to his propaganda activities, the Habsburg government applied to various propaganda activities in order to involve the Christian states in the war on its side and to increase the level of public interest and participation in the defense of the city.
\end{abstract}

Keywords: Ottoman Empire, Habsburg Empire, Vienna, Kara Mustafa Pasha of Merzifon, Propaganda. 
"Murâdım inşâ’allâh Beç’e gitmekdir. Ne dersiz?"

\section{Giriş}

Insanlar tarih boyunca belirledikleri siyasi, sosyal, ekonomik, dinsel vb. amaca ulaşmak için çeşitli araçlara başvurmuşlardır. Bu araçlar içerisinde savaşın ve diplomasinin öne çıtığını söylemek mümkündür. İlk zamanlardan itibaren toplumlar, hedefledikleri amaçlar doğrultusunda çıar çatışmaları yaşamışlar; haklılıklarını ispatlamak, yaptıklarına meşru bir hüviyet kazandırmak, hedef kitleleri yanlarına çekmek ve taraftar kazanmak için gayret göstermişlerdir. Bunu gerçekleştirebilmek için ise propaganda tekniklerine başvurmuşlardır. Bu teknikle birlikte, insanlar tasarladıkları düşünce ve planları uygulamaya koymak için faaliyetlerde bulunmuş, kitleleri ikna etmeye çalışmıslardır. Bu bağlamda, her dönemde ve dünyanın her yerinde, devlet adamlarında, seçkinlerde, diktatörlerde, siyasetçilerde misyonerler aracıllğıyla, bir politik sistemi kabul ettirme, yönetime ve nizama bağlllığı sürdürme, yönetim şeklini değiştirme düşüncesi var olmuştur ve bu düşünceleri filiyata dökme çabalarının hepsi propaganda kavramıyla doğrudan ilişkilidir. ${ }^{1}$

Propaganda, amacı ve doğası gereği sosyal kontrolün önemli bir aracıdır. ${ }^{2}$ Yani kitle psikolojisine hitap eden bir araçtır. Kitleler psikolojisi denildiğinde akla ilk gelen isimlerden olan Gustave Le Bon, bu konudaki incelemelerin daha faklı alanlarda da uygulanabileceğini, bu bilim olmadan birçok tarihî ve ekonomik hadiselerin anlaşılmasının çok güç olduğunu ileri sürmüştür. ${ }^{3}$

Propaganda, Latince kökenli bir kavramdır. Aslen "propagare" sözcügünden türetilmiş olup "bahçıvanin taze bir bitkinin filizlerini yeni bitkiler üretmek için toprağa dikmesi" demektir." Türk Dil Kurumu'nda ise propaganda, "Bir öğreti, dïşünce veya inanc başkalarna tanıtmak, benimsetmek ve yaymak amacyyla söz, yazı vb. yollarla gerçekleştirilen çalısma, yaymaca" ş̧eklinde tanımlanmaktadır. Dilbiliminde propaganda "yaymak,

1 Ahmet Ayhan, Propaganda Nedir?, L-T Literatürk Yayınları, İstanbul 2007, s. 37.

2 Joseph H. Fichter, Sosyoloji Nedir?, çev. Nilgün Çelebi, Anı Yayıncılık, Ankara 2001, s. 185.

3 Le Bon’a göre, kitlelerin psikolojisini anlamak ve insanları birşeyleri yapmaya sürükleyen saikleri ortaya çıkarmak oldukça önemli bir eylemdir. Dolayısıyla L. Bon, bu işleyişin başka bir ifade ile propaganda sürecinin bir maden cevherinin çıartılması ya da bitkilerin incelenmesi kadar faydalı olduğu görüşündedir. Gustave Le Bon, Kitteler Psikolojisi, çev. Hasan Can, Tutku Yayınları, Ankara 2014, s. 19.

4 Fatma Geçikli, "Geçmişten Günümüze Propaganda Kavramı”, İstanbul Üniversitesi İletişim Fakültesi Dergisi, S. 9, 1999, s. 266.

5 Türk Dil Kurumu, Güncel Türkçe Sözlük, "Propaganda", Erişim Tarihi: 19.02.2019, 
ekmek" sözcükleriyle tanımlanmasına karşılık en geniş anlamıyla "hakikati saklamak, tahrif etmek" şeklinde anlaşlagelmiştir. İnsan topluluklarını ötekileştirmesi, birbirinden ayırması ve düşman haline getirmesinden ötürü insanlar, propagandayı daha çok bu manasıyla kabul etmişlerdir. ${ }^{6}$ Ancak günümüzde kavramsal açıdan propagandanın ne olduğuna dair farklı tanımlamalar ileri sürülmüştür.

Propagandanın ne olduğuna ilişkin yapılan ilk tanımlamalardan biri 1923'te R.J.R.G. Wreford tarafindan hazırlanan tezde yer almaktadır. Yazar propagandanın "çirkin" bir sözcük olduğunu iddia ettikten sonra onun "ilgi çekici enformasyon ve kanaat yayma işlemi” olduğunu belirtmiş̧ir.7 Jean M. Domenach'a göre propaganda, bir etkileme girişimidir. Bu girişim sayesinde, kişiler toplumun düşünce ve davranışlarını etkileyerek onların belirli bir görüş ve tutumu benimsemelerini sağlamaktadır. ${ }^{8} \mathrm{Bu}$ tanımlamalardan sonra, propaganda üzerine derinlemesine çalışmalarda bulunan Terence H. Qualter'ın bu konudaki şu ifadeleri konunun hem kavramsal çerçevesini hem de bu hedef doğrultusunda girişilen ya da girişilebilecek davranışlarla ilgili açıklamaları özetleyecek mahiyettedir: “...propagandanm, bir bireyin veya grubun basska bireylerin veya gruplarn tutumlarm belirleyip biçimlendirmek, kontrol altnna almak veya değiştirmek için, haberleşme araçlanndan yararlanarak ve bu bireylerin veya gruplarn belirli bir durum veya konumdaki tepkilerinin kendi amaçlarna uygun tepkiler şeklinde olacağın umarak bilinçli bir faaliyet olarak tanmlanması mümkündür" ${ }^{9}$

Uygulama bakımından propaganda faaliyetlerinin geçmişi ilk çağlara kadar geriye gitmektedir. Başka bir ifadeyle, propagandanın geçmişi insanlık tarihi kadar eskidir. ${ }^{10}$ Öyle ki propaganda, insanlık tarihinin ilk devirlerinden günümüze kadar

20:18, http://www.tdk.gov.tr/index.php?option=com_gts\&arama=gts\&guid=TDK. GTS.5c6c3648c12975.22398672.

6 Osman Özsoy, Propaganda ve Kamuoyu Oluşturma, Alfa Yayınları, İstanbul 1998, s. 6.

7 Terence H. Qualter, "Propaganda Teorisi ve Propagandanın Gelişimi”, çev. Ünsal Oskay, Ankara Üniversitesi Siyasal Bilgiler Fakültesi Dergisi, G 35, S. 1, Ankara 1980, s. 259.

8 J. M. Domenach, Politika ve Propaganda, çev. Tahsin Yücel, Varlık Yayınları, İstanbul 1969, s. 7.

9 Terence H. Qualter, agm., s. 279.

10 Tarihî süreçte, propaganda olarak anılmamış olmasına rağmen uygulanan birçok faaliyetin amacı bakımından onun özelliklerini yansıttı̆̆ görülmektedir. Antik dönemde, M.Ö. 500 yılından evvel, farklı yöntemler aracılığıyla, idarecilerin talep ettikleri düzeni yerleşik kılmak, halkın savaşlara katılımını sağlamak ve iktidarlarını haklı kılmak için propagandadan faydalandıkları bilinmektedir Arsev Bektaş, Siyasal Propaganda Tarihsel Evrimi ve Demokratik Toplumdaki Uygulamalar, Bağlam Yayınları, İstanbul 2002, s. 66. M.Ö. IV. yüzyılda yaşamış olan meşhur Çinli düşünür ve savaş uzmanı Sun Tzu'ya ait "Dïşman savaşmadan yenmek ustalğın doruk noktasıdrr." ifadesinde diplomasiyle birlikte propagandanın önemine işaret ettiği görülmektedir. Bayram Küçükoğlu, Milli Mücadeleden Günümüze Silahsız Terör Propaganda, IQ Kültür Sanat Yayıncllı, İstanbul 2006, 
muhataplarını istenilen düşünceye sevk etmek için önemli bir ikna aracı olmuş, iktidarların sürekli olarak yararlandıkları bir vasıta haline gelmiştir. ${ }^{11}$

Günümüzde ise propaganda faaliyetlerinin daha çok XX. yüzyılda sistemli bir biçimde uygulandığı öngörülmektedir. Ancak kavramsal açıdan propaganda teriminin günümüzdeki manada ilk defa XVI. yüzyılda Katolik Kilisesi tarafindan kullanıldığı bilinmektedir. Yani propagandanın uygulandığı ölçek yirminci yüzyılda çarpıcı bir şekilde artmış olsa da, kelimenin kökeni, Avrupa'nın manevi ve dinî birlikteliğinin paramparça edildiği ve Roma Katolik Kilisesi’nin otoritesinin sarsıldığı Reform dönemine kadar uzanmaktadır. ${ }^{12}$ Vaktiyle bu kavram, Papalık tarafindan Katolik mezhebinin yayılması için kullanılan bir unsur olarak ortaya çıkmıştı. ${ }^{13}$ Kilise'nin dışarıdaki işlerinden sorumlu olan komisyon, bir dış

s. 12. Keza Roma İmparatorluğu döneminde propagandanın birçok liderler veya komutanlar aracılığıyla uygulanışı söz konusudur. Bu amaç doğrultusunda bizzat imparator Neron tarafindan gençlerden meydana gelen ve sayıları beş bine ulaşan "augustales" isminde bir teşkilat kurulmuştur. Sonrasında İmparator, bu propagandacı örgütün vazifesini de belirlemiştir. Buna göre, büyük arenalarda ve sirklerde bir araya gelmiş topluluğu coşturmak, aslanların önünde ölüme terk edilen Hristiyanlık taraftarlarının öldürülmeleri için tezahüratlar yapmak ve halkı galeyana getirmek bu grubun görevleri arasındaydı. Yine Roma'yla birlikte Antik Yunan'da da propaganda diyebileceğimiz farklı etkinlikler vardı. Bunlar, insanların kendi farklılıklarının meşruluğuna insanları inandırmayı amaçlayan uygulamalardı. Bu konuda özgür bireylerin giyim kuşamları, bedenlerini temiz ve sağlıklı tutma konusundaki özenleri, şïr ve felsefe ile uğraşmaları örnek gösterilebilir. Esasında bu faaliyetler, özgür olmayan Atinalıların ve Romalıların gözünde, efendi konumundaki insanların ayrıcalıklı konumlarını meşrulaştırmaya yönelikti. Arsev Bektaş, Kamuoyu, İletişim ve Demokrasi, Bağlam Yayınları, İstanbul 2000, s. 145.

11 Antik dönemde uygulanan çeşitli propaganda etkinlikleri için bk. Garth S. Jowettand Victoria O’Donnel, Propaganda and Persuasion, Sixth Edition, Sage Publications, USA 2015, s. 59-64.

12 XVI. yüzyılın başlarında Katolik Kilisesi'ne karşı Martin Luther’in öncülük ettiği bir Protestan hareketi ortaya çıktı. İlk zamanlarda fazla ciddiye alınmayan Luther'in 1517'de 95 maddeden oluşan bir protesto metni hazırlaması ve bunu Wittenberg şehrinde bir kilise kapısına asması kendilerini Kilise baskısı altında hissedenler tarafından destek bulmasını sağladı. Katolik Kilisesi’nin karşı çıktığı bu hareket ileride yeni bir mezhep olarak ortaya çıkacak ve sürekli bir şekilde aynı görüşe sahip insanları bu çatı altında toplayacaktı. Martin Luther ve onun bu girişimi karşısında Kilise'nin aldığı bazı tedbirler için bk. Philip M. Taylor, Munitions of the Mind, A history of propaganda from the ancient World to the present era, Third Edition, Mancher University Press, Manchester 2003, s. 97-101.

13 J. M. Domenach, Siyasi Propaganda, çev. Cevdet Perin, Yükselen Matbaası, İstanbul 1961, s. 10. Protestanlık güçleri ile reform karşıtı olan Kilise arasındaki mücadele sırasında, Roma Katolik Kilisesi, Katolik olmayan ülkelerdeki otoritesini sürdürme ve güçlendirme sorunuyla yüz yüze gelmiş, Papa XIII. Gregory, putperest olarak nitelendirdiği topraklarda Kilise’nin öğretilerine uymayanları yola getirmek ve Katolikliği yaymakla görevli bir kardinal komisyonu kurmuştu. Nicholas J. Cull ve diğerleri, Propaganda and Mass Persuasion: a Historical Encyclopedia, 1500 to the Presents, New York: ABC-Clio, 2003, s. XVI; Garth S. Jowettand Victoria O’Donnel, age, s. 2; Douglas Walton, "What is Propaganda, and What Exactly is Wrong with It" Public Affairs Quarterly, Vol. 11, 
müdahale olmadan dinsiz kimselere Hristiyanlığın öğretilemeyeceğini öne sürerek vaazlarla onların karanlıktan aydınlığa ulaşmaları için çalışmıştı. ${ }^{14}$ Böylelikle propaganda terimi literatüre ilk kez Roma Katolik Kilisesi'nin 1622 yılında oluşturduğu "Congragatio de Propaganda Fide", yani "Itikadr Tayma Cemiyeti" tarafindan kullanılarak girmiş oldu. Bundan kısa bir süre sonra terim, Protestanlar için olumsuz çağrışımlar uyandırdı. " Dolayısıyla bu kavram, uzun bir dönem günahkâr bir şeyi ima etti. Bu yüzden "propaganda" ile "yalanlar", "aldatma" ve "beyin yıkama" gibi kavramlar iç içe girdi. ${ }^{16}$

Yukarıda, propagandanın esas amacının muhatap kitleyi belirli bir düşünce için ikna etme çabası olduğu belirtilmişti. Bunun yanında zamanla değişen şartlar propagandanın amacından ziyade onun yöntem ve kaynă̆ını değiştirmiş̧ir. $\mathrm{Bu}$ doğrultuda insan ve insan gruplarını ikna etmek için oluşturulan imge ve söylemler dönemin şartlarına göre yeniden şekillenmiş, böylelikle propaganda insanları etkileme ve ikna etme yolunun önemli bir parçası olmaya devam etmiştir. ${ }^{17}$

Propagandayı birçok farklı açıdan irdelemek mümkündür. Bir tarihçi adına propagandada farklı devirlerdeki tarihî etkiler ve günümüz hadiseleriyle mukayeseli değerlendirmeler birinci derecede önemli görülebilir. ${ }^{18} \mathrm{Bu}$ açıdan incelendiğinde, 1683 Viyana Kuşatması'nın bu yaklaşıma örnek teşkil ettiği düşünülebilir. XVII. yüzyılın son çeyreğinde ortaya çıkan ve sonuçları itibariyle gerek Osmanlı Devleti’ni gerekse Habsburg İmparatorluğu'yla ${ }^{19}$ birlikte diğer Batılı devletlerin gelece-

No. 4 (Oct., 1997), s. 383-384.

14 J. A. G. Brown, Siyasal Propaganda, çev. Yusuf Yazar, Ağaç Yayıncılık, İstanbul 1992, s. 11.

15 Werner J. Severin-James W. Tankard, Jr., Iletişim Kuramlan, çev. Ali Atıf Bir-Serdar Sever, Eskişehir: Anadolu Üniversitesi Yayınları, 1994, s. 154.

16 Nicholas J. Cull ve diğerleri, age., s. XV.

17 Yöntem açısından propaganda, beyaz, gri ve kara propaganda olmak üzere üç ana başlıkta incelenmektedir. Bunlar içerisinde beyaz propaganda, kaynağı açık olan bir yöntemdir. Yani bu yöntem açıklık ve şeffaflı̆ğ göz önünde tutar. Ikinci yöntem olan gri propaganda, doğruluğu kanıtlanamayan ve kaynağı belli olmayan bir uygulama şekline sahiptir. Kara propaganda ise, kaynağı belli olmamakla birlikte yalan haber, çarpıtma ve hileli yollarla amacına ulaşmaya çalışır. Söz konusu yollarla gerçekleri saptırmayı, yalanı gerçekmiş gibi sunmayı ve düşmanlı hislerini artırmayı hedefler. Kaynakları bakımından propaganda için bk.Nevzat Tarhan, Psikolojik Savaş, Timaş Yayınları, İstanbul, 2006, s. 36-41.

18 Şeref Ateş, "Bir Siyasal İletişim Tarzı Olan Propagandanın Tanınması ve Propaganda Metinlerinin Çözümlenmesi”, Bilig, S. 13, (Bahar 2000), s. 119.

19 Habsburglar ile Osmanlı Devleti arasındaki münasebetlerin tarihî seyri kronolojik olarak incelendiğinde ilginç bir grafik karşımıza çıkmaktadır. 1529 yllında gerçekleşen I. Viyana Kuşatması'na kadar Habsburgların Türkler hakkında bilgileri çok sınırlı olup Türkler adeta farklı bir dünyaya 
ğini şekillendiren kuşatma, tarihin en önemli siyasi hadiselerinden birisidir. Öyle ki bu olay siyasi, sosyal ve iktisadi açıdan çok kez işlenmesine karşılık bu süreçte ortaya konan propaganda faaliyetleri pek de odak noktası olmamıştır. ${ }^{20}$ Doğu ve Batı'nın kozlarını paylaştı̆̆ bu olayda -sistematik olmamakla beraber- propagandanın çok önemli bir role sahip olduğu dikkat çekmektedir. Zira her iki tarafin seferin karar aşamasından sonuçlanmasına kadar geçen süreçte hedeflerine ulaşmak için birçok propaganda tekniğine başvurduğu görülmektedir. Söz konusu propaganda çabaları dönemin yazılı kaynaklarında açık bir şekilde göze çarpmaktadır.

Propaganda bağlamında ele alınan bu çalışmanın sınıları 1683 Viyana Kuşatması olarak belirlendi. Kuşatma boyunca uygulanan propaganda faaliyetleri ise üç ana başlık altında değerlendirildi. Birincisi, kuşatmanın eşiğinde Kara Mustafa Paşa'nın Orta Macar sorununu ileri sürerek Osmanlı sarayı ve kamuoyu nezdinde bu seferi meşrulaştırma çabalarıdır. İkincisi, sefer kararının ardından kuşatma başlayana dek arka planda gerçekleşen ve propaganda olarak nitelendirilebilecek olan girişimlerdir. Üçüncüsü ise her iki devletin kuşatma esnasında bir yandan kendi taraftarlarını ikna etme ve askerlerin şevkini artırma diğer yandan yıpratıcı faaliyetlerle karşı tarafı moral olarak bozma çabalarıdır.

\section{1683 Viyana Kuşatması'na Doğru: Osmanlı Sarayı'nda Karşıt Fikirler}

Viyana Kuşatması'na giden süreçte -sistemli bir şekilde olmasa da- propaganda kavramı ile açıklanabilecek birçok uygulamanın gerçekleştirildiği görülmektedir. Bir yandan Merzifonlu Kara Mustafa Paşa'nın Osmanlı devlet adamlarını sefere ikna etmedeki başarısında diğer yandan Habsburg İmparatoru I. Leopold'un yoğun ittifak arayışlarında farklı propaganda tekniklerine başvurulduğu görülmek-

ait bir insan topluluğu olarak nitelendirilmiştir. Ancak bu kuşatmadan sonra başlayan gergin ve savaşlarla geçen yıllar Avusturya'da üst düzeye çıkmış bir Türk karşıtı propagandaya neden olmuştur. Öyle ki bu durum, 1683 'te gerçekleşen II. Viyana Kuşatması'na kadar kendisini bütün yoğunluğuyla hissettirmiştir. Bk. Kerstin Tomenendal, "I. Dünya Savaşı'nda Avusturya-Macaristan ve Osmanlı Devletleri Arasındaki Bağlantının Farklı Bir Yönü: Avusturya Menşeli Propaganda Kartpostalları", XIV. Türk Tarih Kongresi, 09-13 Eylül 2002, II. Cilt, II. Kısım, Ankara 2005, s. 1318.

20 Konuyla ilgili yapılan çalışmalardan biri, 2001'de Meryem Kaçan Erdoğan tarafindan hazırlanan doktora tezidir. Erdoğan, "II. Viyana Kuşatması" başlıklı çalışmasında, Osmanlı ordusunun sefer hazırlıklarını ve nasıl organize edildiğini detaylı bir şekilde ele almıştır. Yazar bu bağlamda, ordu ve geri kalan yardımcı kuvvetlerin yanı sıra sefer masrafi, ulaşım, iaşe, ikmal ve geri kalan lojistik faaliyetleri değerlendirmiştir. Yazarın bu çalışması için bk. Meryem Kaçan Erdoğan, II. Viyana Kuşatması, YDT, Marmara Üniversitesi Tiurkiyat Araştrmalar Enstitüsü, İstanbul 2001. 
tedir. Osmanlı cephesinden baktığımızda Merzifonlu Kara Mustafa Paşa seferin meşruiyetini ispat yönünde büyük bir çaba göstermiş; bu doğrultuda Padişah IV. Mehmed'den Valide Turhan Sultan'a, yeniçerilerden kamuoyuna kadar etkili olan girişimlerde bulunmuştur. Habsburg cephesinde ise, Fransa'yla yorucu bir savaştan çıkan imparator Leopold, Avusturya'nın tek başına düşman karşısında duramayacağını düşünerek siyaset ve din merkezli bir propaganda süreci yürütmüştür. Nitekim Osmanlı-Avusturya cenahında yer alan aktörlerin propaganda faaliyetlerini ve bu uygulamaların kuşatma boyunca ne tarzda kullanıldığını anlamak bu önemli hadisenin propaganda bağlamında ele alınmasını anlaşılır kılacaktır.

XVII. yüzyılın ikinci yarısından itibaren Osmanlı Devleti’nde yaşanan siyasi istikrarsızlık Köprülülerin idareyi ele almasıyla yerini Anadolu'da asayişin sağlandığı ve dışarıda yeniden başarılı seferlerin düzenlendiği bir ortama bırakmıştı. ${ }^{21} 3 \mathrm{Ka}$ sım 1676'da Fâzıl Ahmed Paşa'nın ani vefatı üzerine sadaret mührü üvey kardeşi ve eniştesi olan Merzifonlu Kara Mustafa Paşa’ya ${ }^{22}$ teslim edilmiştir. Otoriter, kararlı ve sert bir tabiata sahip olan Kara Mustafa Paşa'nın istikrara kavuşmuş bir idareyi ele alması Avrupalı devletlerce endişeyle karşılanmış; bu gelişme Batı'da yayılan korku ikliminin artmasına neden olmuştur. Zira Kara Mustafa Paşa'nın yabancı devletlerin elçileriyle olan münasebetleri endişe uyandıran cinstendi. ${ }^{23}$

21 Başta Köprülü Mehmed Paşa (1575-1661)'nın ve ardından oğlu Fâzıl Ahmed Paşa (16351676)'nın sadarete gelmesi Batılı devletler nezdinde yeni bir Osmanlı korkusu uyandırmıştı. Nitekim ülkede özlenen istikrar ve huzur sağlanmış; buna paralel olarak Osmanlı Devleti’nin dış politikadaki nüfuz ve otoritesi yeniden güç kazanmıştı. Bu gelişmeler de Avrupa kamuoyunda ciddi bir yankı bulmuştuThomas M. Barker, Double Eagle and Crescent: Vienna's Second Turkish Siege and Its Historical Setting, Albany, New York: State University of New York Press, 1967, s. 108.

22 Merzifonlu Kara Mustafa Paşa aslen Türk olup, 1634'te Merzifon'a bağlı Marınca köyünde doğmuştur. Osmanzâde Taib Efendi, babasını IV. Murad'ın Bağdat seferinde şehit düşen Sipahi Oruç Bey olarak zikreder. Erken yaşlarda babasını kaybeden Kara Mustafa Paşa, babasının yakın dostu olarak bilinen Köprülü Mehmed Paşa tarafindan evlatlık olarak alınır ve bundan sonra üvey kardeşi Fazıl Ahmed Paşa ile birlikte yetiştirilir. Devlet hayatına ilk olarak üvey babasının telhisçisi olarak başlayan Kara Mustafa Paşa, sırasıyla mîrâhûr-1 sânilik, Silistre beylerbeyliği, Diyarbakır beylerbeyliği, kaptan-ı deryalık ve kaymakamlık ve ardından sadrazamlık vazifelerini yürütmüştür. Ayrıntılı bilgi için bk. Osmanzâde Taib Ahmed, Hadikatü'l-Vüzerâ, haz. D. Robischon, Freiburg 1969, s. 109; Râşid Mehmed Efendi-Çelebizâde İsmâil Âsım Efendi, Târîh-i Râşid ve Zeyli, haz. Abdülkadir Özcan ve diğerleri, C I, Klasik Yayınları, İstanbul 2013, s. 257; Mehmed Süreyya, Sicill-i Osmanî, G IV, haz. Nuri Akbayar, Tarih Vakfi Yurt Yayınları, İstanbul 1996, s. 1198; Münir Aktepe, "Mustafa Paşa, Merzifonlu, Kara", Íslam Ansiklopedisi, G 8, Milli Eğitim Basımevi, İstanbul 1979, s. 736.

23 Örneğin Fransız elçi Marquis de Nointel’in yaşadığı iskemle gerginliği ve ardından karşılaştı̆̆ı ağır muameleler elçi tarafindan hakaretvâri bir uygulama olarak görülmüştü. Meşhur iskemle vakası, Fransız elçi Nointel'in sadrazamla aynı hizada oturmak istemesine karşın bu isteğinin ısrarla 
Sadrazam'ın bu katı diplomasi politikası doğal olarak Batı dünyasında hakkında olumsuz bir imajın doğmasına, Hristiyan dünyasının amansız düşmanı kimliğine bürünmesine neden olmuştu.

Kara Mustafa Paşa, sadaretinde ilk olarak Kazak meselesini ele almış; 1677'de patlak veren bu sorunu Ruslarla yapılan Çehrin Antlaşması (1681) ile sonuçlandırmıştı. ${ }^{24} 1681$ 'de barış antlaşmasıyla sona eren Osmanl-Rus mücadelesinden sonra Türklerin fetih siyasetini sürdüreceği beklenen bir gerçekti. ${ }^{25}$ Öyle ki söz konusu dönemde Orta Avrupa'da yaşanan gelişmeler Kara Mustafa Paşa'nın yönünü bu bölgeye çevirmişti. Katolik Habsburglar, nüfuzunu artırmak için bölgedeki Protestan Macarlara baskı uygulamakta, kendi inanıslarına göre sapkın bir mezhebe mensup Macarlara belli aralıklarla saldırılarda bulunarak onları zor durumda bırakmaktaydı. Bundan başka, Habsburg İmparatoru bir yandan Macar ayaklanmasını sakinleştirmeye çalışırken öte yandan Edinburg'da meclisler ayarlayıp önemli Macar liderlerini müzakerelere davet etmekteydi. Imparator, Macar ileri gelenlerini ikna etmek için beyannameler yayınlamaktaydı. Fakat isyancı Macar beyleri tam tersine hareket etmekte ve "Vatanımızm saadet ve selameti için Allah'm himayesinden sonra en kıymetli yardımcımı Osmanhlardrr."26 diyerek Habsburglar karş1sında Osmanlı Devleti'ne duydukları güveni dile getirmekteydi.

İmparator, Macar temsilcilerini ikna etme uğrundaki propaganda çalışmaları sonuçsuz kalınca, Protestan Macarların zor yollarla Katolik mezhebine dönmeleri için uğraştı. ${ }^{27}$ Baskıya maruz kalan Macar toplulukları Tökeli İmre’nin liderliğin-

geri çevrilmesinden kaynaklanan bir hadisedir. İskemle hadisesi hakkında detaylı bilgi için bk. Ahmet Refik Altınay, Osmanl'nn Felaket Seneleri (1683-1699), 2. Baskı, Haz. Muammer Yllmaz, İlgi Kültür Sanat Yayıncllı, İstanbul 2017, s. 17; Sevil Gözübüyük, "Osmanlı-Fransa İlişkilerinde Diplomatik Protokol Unsuru Olarak "İskemle" (XVI.-XVII. Yüzyllar)", ASEAD, C 5, S. 6, 2018, s. 111-112. Yine veziriazamlığı döneminde Leh elçisi Jan Gninski de Kara Mustafa Paşa tarafindan itibarsız kılınmış ve kayda değer görülmeyen hareketlerle karşılaşmıştı. Veziriazamla görüşmek isteyen ancak umduğu beklentilerle karşılaşamayan elçi Jan Gninski’nin yaşadığı süreç için bk. Karolina Anna Kotus, Polonyalı Elçi Jan Gniński'nin Türkiye Seyahatnamesi'ne Göre Osmanlı Ülkesi ve Osmanlılar (1677-1679), YYLT, Hacettepe Üniversitesi Türkiyat Araștrmalan Enstitiisü, Ankara 2015, s. 38-42.

24 Akdes Nimet Kurat, Rusya Tarihi Başlangz̧̧tan 1917’ye Kadar, 6. Baskı, Türk Tarih Kurumu Yayınları, Ankara 2014, s. 252.

25 John Stoye, İkinci Viyana Kuşatması, Çev. Selahattin Atalay, Dilek Matbaası, İstanbul 1984, s. 125.

26 Yine aynı dönemde Fransa kralı XIV. Lui, Osmanlı Devleti’ni doğrudan Avusturya ile bir harbe teşvik etmese de ayaklanan Macar beylerini destekliyor ve Tökeli İmre'yi tahrik ederek kendisini Macaristan'ın hamisi olarak addediyordu. Ahmet Refik Altınay, age., s. 20.

27 Avusturya imparatoru I. Leopold, Avusturya tahtına geçtikten sonra Macarların din ve hürriyet 
de Osmanlı Devleti'nden himaye talep ettiyse de Fâzıl Ahmed Paşa döneminde Vasvar Antlaşması (1664) gereğince istekleri geri çevrilmişti. Osmanlı Devleti'nde yaşanan sadaret değişikliğiyle Tökeli İmre birçok hediye yollayarak Kara Mustafa Paşa'dan Avusturya'ya karşı yardım talebinde bulundu. ${ }^{28}$ İşte böyle bir ortamda, Sadrazam birçok devlet ricalinin muhalefetine rağmen yoğun bir propagandayla Padişah'ı ve saraylıları ikna ederek Osmanlı Devleti'ni Habsburglara karşı yeni bir savaşa sürükledi.

Avusturya üzerine sefer isteyen Sadrazam'ın bu amacina mani olabilecek önemli engeller söz konusuydu. Bir yandan IV. Mehmed ve devlet adamlarından bazıları Avusturya'ya karşı bir sefere çıkmak istemezken öte yandan 1664'te St. Gotthard Muharebesi sonucu imzalanan ve 20 yll geçerliliği olan Vasvar Antlaşması'nın süresi henüz bitmemişti. ${ }^{29}$ Bununla birlikte Osmanlı kamuoyunun bu sefere ikna edilmesi ve onlardan destek alınması Kara Mustafa Paşa'nın aşması gereken başka bir önemli adımdı. Kuşkusuz bu engellerin ortadan kalkması etkili bir propaganda ile gerçekleşebilirdi.

Sadrazam'ın Padişah'ı bu sefere teşvik ve ikna edebilmesinde Orta Macaristan'da yaşanan gelişmeler iyi bir bahane olarak göründü. ${ }^{30} \mathrm{Bu}$ doğrultuda Sadrazam, Budin Beylerbeyi Arnavud İbrahim Paşa'yı Tökeli İmre’ye yardım etmek üzere görevlendirdi. ${ }^{31}$ Osmanlı Devleti'nin bu himayesiyle daha cesur hareket eden Tökeli, beraberindeki 12 bin kişilik kuvvetiyle birlikte "Allah ve vatan için" yazılarını içeren bayraklarıla Habsburglara ait bölgelere akınlar düzenledi. ${ }^{32}$ Tökeli ve ona destek

özgürlüklerine karşı son derece şiddetli bir politika izlemiş; bu doğrultuda Macar topraklarında geniş bir alana yayılan Protestanlık mezhebini zayıflatıp Katolikliği güçlü kılmak amacıyla bölgeye çok sayıda Cizvit papazını göndermiştir. Bu papazlar bölge halkını kendilerine çekmek için propaganda girişiminde bulunmuşlar, ikna olmayan kesim üzerinde şiddetli korkutma politikaları uygulamışlardır. Bk. Cevat Üstün, 1683 Viyana Seferi, 2. Baskı, Türk Tarih Kurumu Yayınları, Ankara 2010, s. 18-19; Zuhuri Danışman, Osmanh İmparatorluğu Tarihi, G X, Yeni Matbaa, İstanbul 1965, s. 49.

28 N. Karaçay Türkal, Silahdar Fındıklılı Mehmed Ağa, Zeyl-i Fezleke (1065-22 Ca.1 106 / 1654-7 Şubat 1695) Tahlil ve Metin, YDT, Marmara Üniversitesi Türkiyat Araştrmalan Enstitïsï, İstanbul 2012, s. 770-771.

29 Abdülkadir Özcan, "Viyana Bozgunun Maddi ve Manevi Sebepleri Dönemin Kısa Panoraması", Merzifonlu Kara Mustafa Paşa Uluslararast Sempozyumu (Merzifon-Amasya, 8-11 Haziran 2000), Ankara 2001, s. 231.

30 Dimitri Kantemir, Osmanl İmparatorluğunun Yükseliş ve Çöküş Tarihi, G 3, çev. Özdemir Çobanoğlu, Kültür Bakanlı̆̆ Yayınları, Ankara 1980, s. 32.

31 N. Karaçay Türkal, agt., s. 780; Zuhuri Danışman, age., s. 50.

32 İsmail Hakkı Uzunçarşılı, Osmant Tarihi, II. Selim’in Tahta Çıkı̧sından 1699 Karlof̧̧a Andlaşmasina 
olan Osmanlı birliklerinin girişimleri Viyana hükümeti tarafindan endişeyle karşlanıyor; bu durum, daha ileride kendi topraklarına düzenlenebilecek bir seferin işareti olarak algılanıyordu. ${ }^{33}$ Öyle ki bu gelişmeleri "Bu hasâretler Nemçe diyarna numunedir." diyen ve telaşa kapılan İmparator Leopold 3 Şubat 1682'de Vasvar Antlaşması'nın hükümlerini yenilemek ve sulhun müddetini uzatmak amacıyla orta elçisi Kont Alber de Kaprara'yı İstanbul'a gönderdi. ${ }^{34}$ Ancak Kaprara'nın girişimleri, kendisinden önce aynı amaçla görevlendirilen elçi Khunitz’inkinden farksızd. ${ }^{35}$ Bundan sonra Sadrazam Kara Mustafa Paşa'nın izlediği siyaset ve girişimleri onun bu süreçte ne derecede etkili bir propaganda süreci yürüttüğünü anlamamız bakımından kayda değerdir. Nitekim sefere karar verilmeden önce, yeni bir barış antlaşmasına karşı çıkan Sadrazam kendi görüşüne katılmayanları etkilemek ve kendi fikirlerini aşılamak için türlü propagandalara başvurmuştur.

Sadrazam, Orta Macaristan seferi için gereken ortamı ciddi bir titizlikle oluşturmaya gayret etmekteydi. Öte yandan Tökeli İmre, 9 Nisan 1682'de Habsburglarla sürdürdüğü görüssmeleri sonlandırdıktan 20 gün sonra Arnavud İbrahim Paşa ile görüşmek amacıyla Budin'e geldi. ${ }^{36}$ Bu yeni gelişmeler İmparator tarafindan endişeyle karşılanmıştı. Barışı tesis etmek için yollanan Kaprara 1682 Mayıs'ında İstanbul'a ulaşmış, yetkililer tarafindan onurlu bir şekilde karşılanmışsa da müzakere girişimleri sonuçsuz kalmışt. ${ }^{37}$ Dîvân-1 Hümâyûn'a davet edilen Kaprara, beraberindeki hediyeleri sunup nâmesini arz ettikten sonra yaşanan son gelişmelerden dolayı Viyana hükümetiyle görüşmeler gerçekleştirilmesini talep etti. ${ }^{38} 10$ Haziran 1682'de elçinin bu isteğine karşllık Padişah, "Pek iyi, pek iyi, devlet erkâniyle görüşülsün." şeklinde yanıt vererek sulha meyilli olduğunu gösterdi. ${ }^{39}$ Ancak Padi-

Kadar, G III, 6. Baskı, Türk Tarih Kurumu Yayınları, Ankara 1988, s. 435.

33 N. Karaçay Türkal, agt., s. 784.

34 N. Karaçay Türkal, agt., s. 784; Karl August Schimmer, The Sieges of Vienna by the Turks, translated from the Germany by the Earl of Ellesmere, John Murray, London 1879, s. 73.

35 J. W. Zinkeisen, Osmanl İmparatorluğu Tarihi, C 5, çev. Nilüfer Epçeli, Yeditepe Yayınevi, İstanbul 2011, s. 66. Savaşın öncesinde, iki devlet arasında gerçekleştirilen diplomatik temaslar ve harbe giden süreç hakkında hazırlanmış kıymetli bir çalışma için bk. Yasir Yılmaz, The Road to Vienna: Habsburg and Ottoman Statecraft During the Time of Grand Vizier Kara Mustafa Paşa (1676-1683), PhD Dissertation, Purdue University, Indiana 2015.

36 Râşid Mehmed Efendi-Çelebizâde İsmâil Âsım Efendi, age., s. 230-231; Cevat Üstün, age., s. 23.

37 Johann W. Zinkeisen, age., s. 65-66.

38 N. Karaçay Türkal, agt., s. 784-785.

39 İsmail Hakkı Uzunçarşılı, age., s. 437. 
şah'ın bu tavri ${ }^{40}$, başından beri sefer arzulayan Sadrazam'ın hoşuna gitmemiş, bu sebeple onun gözünde düşman bir Habsburg imajı yaratmak adına onların sulha karşı harekette bulunduklarını ileri sürerek kendi fikirlerinin haklıllğını ispata çalışmışır. ${ }^{41}$

Sadrazam'in yeni bir sefer için öncelikle devlet erkânını ikna etmesi ve bu seferi halkın gözünde meşru kılması gerekmekteydi. Bu savaşa Osmanlıların değil de Habsburgların neden olduğu imajı iyi bir malzeme olarak görünmekteydi. Ancak bu konuda başarı güçlü bir propagandayla gerçekleşebilirdi. Propagandanın en önemli malzemelerinden olan sözlerin gücü dikkate alındığında, bu süreçteki telkinlerin önemi daha iyi anlaşılmaktadır. Bu hususta, belli slogan ya da anahtar sözcükler propagandacının işine yarayan önemli unsurlardır. Kara Mustafa Paşa'nın da en önemli argümanlarından birisi telkinlerdir; bunların da intikam hırsını güdüleme yönünde olduğu görülmektedir. Sadrazam’ı hareketli, açgözlü, savaşa meyilli ve devletin sonunu düşünmeyen gururlu bir Türk olarak kaydeden Silahdar Findıklılı Mehmed Ağa, onun 1664'teki St. Gotthard Muharebesi'nde yaşanan başarısızlığı telafi etmek ister gibi görünerek Padişah'ı etkilemeye çalışt1ğını belirtir. Bunun için Sadrazam'ın “Üzerimize Raba cenginde bulaşan yağl kara henüz dahi silinmeyüp kaldd." gibi sözlerle Padişah'ı tahrik ettiğini kaydetmektedir. ${ }^{42}$ Sadrazam tarafindan intikam fikrinin ısrarla ileri sürülmesi şüphesiz IV. Mehmed'in fikrinin değişmesinde etkili olmuştur. Kaynakların bize sunduğu bu durum, yaşanmış bir gerçekliği açı bir şekilde muhataplarına hatırlatması yönüyle aynı zamanda beyaz propagandanın güzel bir örneğini teşkil etmektedir.

Kara Mustafa Paşa, gerektĭginde Padişah'nn bilmesini istemeyeceği gelişmelerin de gündeme gelmesini engellemiştir. ${ }^{43}$ Nitekim amaca aykırı olacak veya muhatapla-

40 Osmanlı tarihlerinde Sadrazam'ın özellikle Macarlara yardım etmek ve bu niyetle sefere çımak için IV. Mehmed'i ikna etmeye çalıştığı belirtilirken, Dimitri Kantemir Padişah'ın Kara Mustafa Paşa ile aynı görüsste olduğunu kaydetmektedir. Kantemir'e göre Padişah, bu seferin Osmanlı toplumu için ağır bir yük olacağını bildiğinden muhtemel bir muhalefeti engellemek amacıyla devlet hazinesinde yetmiş bin kese altın mevcut olduğunu, müthiş bir ordunun varlığını ve birkaç seferi idare edebilecek kadar tüm ihtiyaçlara sahip bulunduklarını beyan etmiştir. Bk. Dimitri Kantemir, age., s. 33-34. Kantemir'in bu görüşüne N. Jorga'nın da katıldı̆̆ı görülmektedir. Bk. Nicolae Jorga, Osmanl İmparatorluğu Tarihi (1640-1774), C 4, çev. Nilüfer Epçeli, Yeditepe Yayınları, İstanbul 2009, s. 167.

41 Râşid Mehmed Efendi-Çelebizâde İsmâil Âsım Efendi, age., s. 231.

42 N. Karaçay Türkal, agt., s. 785; Mustafa Nuri Paşa, Netayicül-Vukuat, Kurumlan ve Örgütleriyle Osmanh Tarihi, C I-II, sad. Neşet Çağatay, Türk Tarih Kurumu Yayınları, Ankara 1987, s. 282; İsmail Hakkı Uzunçarşllı, age., s. 437.

43 Daha sadaretinin ilk yllarında, Macar asillerinin temsilcileri 1677'de yeniden İstanbul'a geldiklerinde Sadrazam tarafından yardım sever bir şekilde karşılanırlarken, bu temsilcilerin Babıali 
rının dikkatini dağıtabilecek hakikatlerin gizlenmesi propaganda sürecinin önemli bir parçasıdır. ${ }^{44}$ Dolayısıyla Padişah'ı tamamen ikna edemeyen Sadrazam'ın hileli yollara müracaat ettiği de görülmektedir. Bu açıdan bakıldığında, kara propaganda faaliyetleri de Merzifonlu'nun yürüttüğü siyasette mühim bir role sahiptir. Aşağıdaki örneklerde görüleceği üzere, Kara Mustafa Paşa sahte delillerle hatanın düşman tarafinda olduğu düşüncesini zihinlere işlemeye gayret etmiştir. Beyaz propagandanın aksine yalan haber, hile ve çarpıtma gibi yollara dayanan kara propaganda faaliyetleriyle başta Padişah olmak üzere hedef kitlelerin Habsburg hükümetine karşı izledikleri politikada bir zihin karışıklığı yaratılmak istenmiştir.

Mesela Sadrazam serhad beylerine şikâyetnameler içeren mektupların merkeze gönderilmesini emretmişti. Öte yandan eşkıya taifesinden kimseler Viyana sınırlarında yağma faaliyetlerinde bulunmakta, ele geçirdikleri esir ve eşyaları sınırı korumakla görevli askerlerin haricinde bölgenin kadı, müftü, imam, hatip ve müezzinleriyle paylaşmaktaydı. Buna karşın Viyana hükümetinden Osmanlı merkezine sınırda gerçekleştirilen bu tacizlerin ortadan kaldırılması için şikâyetler iletiliyordu. Osmanlı padişahı sınır beylerine ve komutanlara Habsburglarla olan sulhun aksine bir girişimde bulunulmamasına yönelik emirnameler göndermişse de sınır boylarından gelen arzlar kabahatin düşman tarafinda olduğunu belirtiyordu. Hatta Estergon Beği bu arzları destekleyen yakınmalarda bulunmuş, buna karşılık işin sonunu düşünmeyenler gurura kapılarak Habsburg İmparatoru'nun Osmanlı'nın bir tuğlu beyine karşı yakınmasını iftihar olarak addedmişti. ${ }^{45}$ Bununla birlikte, merkezden yardım talep eden bu feryâdnâmelerde halkla beraber tacirler ve yolcuların mağdur oldukları belirtilmişti. Sultan IV. Mehmed'in hâlâ sefere razı olmaması üzerine, başta onun hocası Vânî Mehmed Efendi olmak üzere selâtîn kürsülerinin vaizlerine görev verilerek kamuoyunu sefere ikna için vaazların verilmesi sağlandı. ${ }^{46}$ Neticede sınır boylarından gönderilen sahte mektupları bir ikna aracı

ile müzakerelerine karşı çımak isteyen imparatorluk elçisi Kindsberg sınırlarda ortaya çıkan karışıklıklardan ötürü huzura alınmamıştı. Bk. Johann W. Zinkeisen, age., s. 64-65.

44 Fatma Geçikli, "Geçmişten Günümüze Propaganda Kavramı", İstanbul Üniversitesi İletişim Fakültesi Dergisi, S. 9, 1999, s. 268.

45 N. Karaçay Türkal, agt., s. 785; Göker İnan, Hasan Esîn̂’nin Mi'yârü’d-Diüvel ve Misbârü'l-Milel İsimli Tarih ve Coğrafya Eseri (İnceleme-transkripsiyon), YDT, Marmara Üniversitesi Türkiyat Araştırmaları Enstitüsü, İstanbul 2017, s. 1384-1385; Ahmet Refik Altınay, age., s. 27.

46 N. Karaçay Türkal, agt., s. 785; Abdülkadir Özcan, a.g.m, s. 231. Yukarıda kavramsal olarak propagandayı tarif ederken modern propagandanın ilk kez Katolik Kilisesi tarafından sistemleştirildiğinden bahsetmiştik. Bu bakımdan ele alındığında propaganda ile din (inanç) arasında oldukça güçlü bir bağın bulunduğu anlaşılmaktadır. Nitekim Islam inancı için de benzer bir durumun söz 
olarak kullanan Sadrazam, Padişah'a bölgede bulunan birçok kale ve beldenin Avusturyalılar tarafından rahatsız edildiğini belirterek kendilerinin izni dâhilinde kullarının sefere çıkmak istediğini ifade etmiştir. ${ }^{47}$

Viyana hükümetiyle sulha yanaşmayan ve yoğun propaganda faaliyetlerine devam eden Kara Mustafa Paşa, etkilemek istediği kitlelerin beklentilerinin farkında olan birisiydi. Buna göre hareket eden Sadrazam, Osmanlı Devleti’nin askerî sisteminde nüfuzlu bir role sahip yeniçeri ocağının desteğini almaya çalıştı. Zira yeniçerilerin sefere, dolayisıyla ganimete olan arzusu Sadrazam tarafindan bilinen bir gerçekti. Bunun farkında olarak Sadrazam, öncelikle Yeniçeri Ağası Bekrî Mustafa Paşa'yı kendi yanına çekmiş ve onun yeniçeri askerleri üzerindeki otoritesini kullanmıştır. Bu suretle Padişah’ın karşısına çıkan Bekrî Mustafa Paşa sefere razı edilen yeniçerilerin ağzından "Pâdişâh bizi niye besler, oturmadan kötürüm olduk. Ceng isteriz. Râba'dan kalan câme-dânlarmıı varup düsmenden alalım." sözleriyle askerlerin sefer için ısrarlı olduklarını ifade etmiştir. Kara Mustafa Paşa tarafindan galeyana getirilen yeniçeriler ve bunlara omuz çıkan komutanlar savaşmak istediklerini belirtmiş; hatta daha ileri giderek Osmanlı himayesindeki Macarlara zulmeden Habsburg İmparatoru'na karşı ölmeyi göze aldıklarını açıkça bildirmişlerdi. ${ }^{48}$

Kara Mustafa Paşa'nın ikna etmesi gereken kişiler bunlarla sınırlı değildi. Nitekim nerdeyse bütün ulema hatta Valide Sultan dahi herhangi bir şikâyete meydan vermeyen bir imparatora yönelik sefere çıkmanın yanlış olduğunu savunmuş; tersine, o güne kadar barış antlaşmasının şartlarına kesin surette bağlı kaldıklarını vurgulamıştır. Buna karşılık Sadrazam ise, demirin tavında iken dövülmesi gerektiğini ve İslam dinini yaymak için daha uygun bir ortamın ele geçmeyeceğini ileri sürmüş̧ür. Zira ona göre Hristiyan dünyasının önemli bir kalesi olan Macaristan, kendi arzusuyla boyun eğmek istiyordu. Habsburglar ise Fransa ve İsveç’le yapılan savaşlardan ötürü güç kaybetmiş olup gafil avlanabilirdi. Bu sebeple Sadrazam, düşüncelerine muhalif olan Valide Sultan'ı ikna etmeye çalışmış; bu doğrultuda ona yeni seferler düzenlendiği takdirde paşmaklığının otuz kese daha artacağı sözünü vermiş ve böylece onu da yanına çekmiştir. Valide Sultan’ın Sadrazam’ın görüşünü kabul etmesi üzerine bu hususta düşüncesini uzun bir süre gizli tutan

\footnotetext{
konusu olduğu söylenebilir. Tekinsoy’un propaganda faaliyetlerinde vaazların rolünü incelediği çalışması için bk. Yunus Emre Tekinsoy, "Birinci Balkan Savaşı'nda Bir Propaganda Unsuru Olarak Vaaz", Sosyal Bilimler Araşttrmalan Dergisi (SBAD), Kış 2018, 13/2, s. 321; 323.

47 Uğur Demir, Târîh-i Mehmed Giray, YYLT, Marmara Üniversitesi Türkiyat Araștrmalan Enstitiusü, İstanbul 2006, s. 3.

48 Dimitri Kantemir, age., s. 34-47.
} 
Şeyhülislam da razı olmuş ve Sultan'ın düşüncesini bir fetva ile onaylamıştır. ${ }^{49}$

Sadrazam’ın muhataplarını iknaya yönelik bütün bu girişimleri karşısında hâlen sefere razı olmayan kitleler de mevcuttu. Mesela Merzifonlu'nun gördüğü bir rüyayı yorumlayan Hasan Efendi kendisine bu sefer fikrinden vazgeçmesi yönünde telkinlerde bulunmuş; ancak Sadrazam bu tavsiyeleri reddetmiştir. ${ }^{50}$ Bütün bunlara karşın aksi yönde düşünenler yatı̧mayıp barış antlaşmasına taraftar olanlar Sadrazam'ın bu fikrinin Sultan Süleyman'ın lanetine karşı bir girişim olacağını ve Osmanlı halkının haksız bir seferi istemediğini belirten farklı isimsiz mektupları yoğun bir şekilde divanın aleyhine göndermişlerdir. ${ }^{51}$ Kara Mustafa Paşa'ya muhalif olanlar can sıkan ve tahrik eden tenkitleriyle Sadrazam'nn bu askerî girişiminin karşısında durmuşlardır. ${ }^{52}$ Ancak tüm bu karşı propagandalara rağmen IV. Mehmed bir hatt-1 hümayunla Orta Macar siyasetini Kara Mustafa Paşa'ya havale etti..$^{53}$

Sadrazam yaptığı propaganda çalışmalarında başarılı olmuş ve ipleri eline almış görünmekteydi. Öyle ki daha önce 1682 Nisan'ında başlayan ve Temmuz ayında Tökeli İmre ile Budin Valisi İbrahim Paşa arasında akdedilen ahitname onaylanmak üzere Sadrazam'a sunulmuştu. ${ }^{54}$ Bu durumu iyi değerlendiren Kara Mustafa Paşa İstanbul'da 10 Ağustos 1682 'de bu ahitnamenin kabulü niteliğinde bir berat hazırlanmasına ön ayak olmuş, Eylül ayının bitiminde sancak ve tuğla beraber Tökeli'ye gönderilmesini sağlayarak onun Orta Macar Kralı ilan edilmesine firsat tanımışt. ${ }^{55}$

İmparator'un elçisi Kaprara ise Orta Macaristan üzerine bir sefer istemeyenlerin olduğu ortamdan faydalanacağını düşünmüştü. Ancak onun müzakere talebi,

49 Dimitri Kantemir, age., s. 33-34; Karl August Schimmer, age., s. 74-75.

50 Silahdar Tarihi'nde bu rüyayla ilgili geçen kayıt mealen şöyledir. Sadrazam ayağına yeni bir çizme giyip yürüdüğü bir sırada karşısına yedi başlı bir ejderha çıkmakta ve bu ejderha Sadrazam’ın üzerine yürüyerek onu sokmaktadır. Rüyayı yorumlayan Mu'abbir Hasan Efendi, giyilen çizmenin büyük bir sefere işaret ettiğini, görülen ejderhanın da emrinde yedi kral olan Habsburg İmparatoru olduğunu ifade etmiş, ardından seferden vazgeçilmesinin hayırlı olduğunu aksi takdirde sonucun pişmanlık vereceğini belirtmişse de Kara Mustafa Paşa fikrinden geri dönmemiştir. Bk. N. Karaçay Türkal, agt., s. 785.

51 Dimitri Kantemir, age., s. 34.

52 John Stoye, age., s. 71.

53 Uğur Demir, agt.,s. 3.

54 Cevat Üstün, age., s. 23.

55 Johann W. Zinkeisen, age., s. 65. 
Sadrazam'ın savaşa olan isteği ve kabul edemeyeceği barış şartlarından dolayı sonuçsuz kalmıştı. Elçi Kaprara 28 Aralık’ta Kara Mustafa Paşa’ya bin beş yüz altın parayla dolu bir gümüş vazo takdim etmişti. Sunduğu paraların her biri 12 Macar altın sikkesi ağırlığındaydı. Kaprara Sadrazam’a sefer hazırlıklarının imparatorunu telaşlandırdığını, fakat iki devlet arasındaki barışı yenilemek hususunda kendisinin tam yetkili kılındığını belirterek seferle ilgili dedikoduları umursamadığını dile getirdi. Buna karşılık Sadrazam, Padişah’ın bu konudaki fikrini onun İstanbul'a geri dönmesinden sonra haber vereceğini, aynı zamanda imparatorun barış konusunda iyi niyet gösterisinde bulunması için Neuhasel yakınlarında bulunan yetmiş küçük şehir, köy ve kasabayı kendilerine bırakması için acele etmesi gerektiğini ifade etti. ${ }^{56}$ Bunun yanında Kaprara'nın önüne sürülen barış şartlarında başta Leopoldstadt olmak üzere, inşa edilen yeni kalelerin yıkılması, Uyvar civarındaki köylere ilişkin haracın alınması ve kaçak durumdaki esirler için tazminat istenmesi gibi talepler de geliyordu. ${ }^{57}$ Sadrazam'ın elçiden istekleri bunlarla sınırlı değildi. Sefer için harcanan masrafların da Avusturya tarafindan karşılanmasını talep etti. ${ }^{58}$ Şüphesiz tüm bu istekler, Avusturya üzerine sefere çıkmak isteyen Sadrazam için elçi Kaprara’yı oyalamak ve bu doğrultuda sefer hazırlıkları için zaman kazanmak anlamına gelmekteydi.

Bu gelişmeler üzerine umutsuzluğa kapılan elçi Kaprara, imparatorun kendisini mal veya toprak vermek için değil yalnızca barışı yenilemek amacıyla vazifelendirdiğini dile getirmiş, daha sonra Sadrazam'a yakınmalarda bulunmuştu. Hatta devrin şeyhülislamı Ali Efendi'nin yanına giderek "Şerî'at-i Muhammedî üzre boğazına makrame takup, emân diyene kılıç olur mı? Üzerine sefer câ’iz midir?" diyerek seferden vazgeçilmesini istemiş; Şeyhülislam'dan bu girişimin meşru olmadığına dair fetva almaya çalışmış ancak Sadrazam bu durumu umursamayarak elçiyi göz hapsine aldirmiştı. ${ }^{59}$

Kara Mustafa Paşa IV. Mehmed'den aldığı yetkiyle Yeniçeri Ağası Bekrî Mustafa Paşa'ya elçi Kaprara’yı huzuruna almasını ve kendi tekliflerinin yeniden iletilmesini istemişti. Bunun üzerine Yeniçeri Ağası huzuruna gelen elçiye Raab’ın yani 17.

57 Nicolae Jorga, Osmanl Imparatorluğu Tarihi (1640-1774), C 4, Çev. Nilüfer Epçeli, Yeditepe Yayınları, İstanbul 2009, s. 166.

58 N. Karaçay Türkal, agt., s. 785.

59 N. Karaçay Türkal, agt., s. 785-786; Uğur Demir, agt., s. 3; İsmail Hakkı Uzunçarşılı, age., s. 438. 
Yanıkkale'nin Osmanlı Devleti'ne geri verilmesi halinde barışın sağlanabileceğini ifade etmişti. Ancak elçi Kaprara yetkisini de aşarak Yeniçeri Ăgassna, "Kal'a kılıç ile dâhil-i kabza-i teshîre getürilür yohsa bundaki söz ile kal'a virilmez" diyerek savaşmadan kalenin teslim edilmesinin söz konusu olmayacağını dile getirmiştir. Daha sonra Bekrî Mustafa Paşa'nın da "Peki öyle ise biz de memleketinize gideriz. Biz Türkler, şu ayağımızın bastı̆̆ yerlere hep kılıc kuvvetiyle geldik. Sulh kapısın ancak bizi hoşnut edenlere açabiliriz." demesi üzerine Kaprara durumun ciddiyetini kavramış oldu. Devlet erkânı bir araya gelerek savaş konusunda istişarede bulundular ve çıkartılan hatt-1 hümayunla 21 Ocak 1683'te savaş tuğları sarayın önünde Macaristan tarafina dikilerek savaş resmen ilan edilmiş oldu. ${ }^{60}$

Görülen o ki, Kara Mustafa Paşa, Avusturya'ya savaş açılması hususunda propagandadan etkin bir şekilde faydalanmıştır. Nitekim Padişah IV. Mehmed'den Valide Sultan'a, ileri gelen devlet adamlarından ulemaya kadar önemli bir kesimin Habsburg üzerine düzenlenebilecek bir sefere dair düşüncelerini yeniden şekillendirmiş, Avusturya üzerine sefer kararının çıkmasında en etkin rolü oynamıştır. ${ }^{61}$

\section{Türkler İçin Kötü İşaretler ve Avusturya'da Bunalım}

Sultan IV. Mehmed’in öncülüğünde Kara Mustafa Paşa ve Osmanlı birlikleri sefere çıkmak üzere hareket etti. Seferin başlangıcından kuşatmanın gerçekleştiği tarihe kadar yaşananlar Türk tarafının propagandasının bir diğer önemli yönünü teşkil etmekteydi. Nitekim sefer harekâtının başlamasıyla birlikte yaşanan hadiseler o ana kadar yapılan propaganda girişimlerine bir karşı duruşu ortaya koymaktaydı. Her firsatta Habsburglar üzerine bir sefer arzu eden Sadrazam bundan sonra kendi fikirlerine yönelik yürütülen karşı propagandaların önünde durmaya çalışmış, yeri geldikçe mevki ve otoritesini kullanarak zorla emirlerine itaat edilmesini sağlamıştır.

Sefer kararından birkaç gün sonra Sadrazam'la birlikte müftü, kazasker ve ileri gelen devlet adamları İstanbul'dan Edirne'ye hareket etti. Edirne'ye varıncaya kadar rahat bir yürüyüş amacıyla İstanbul'dan yaklaşık bir mil uzaklıkta bulunan Çırpıcı

60 N. Karaçay Türkal, agt., s. 791; Mustafa Nuri Paşa, age., s. 282; Abdurrahman İsa Efendi, İsâzâde Târîhi, haz. Ziya Yılmazer, İstanbul Fetih Cemiyeti, İstanbul 1996, s. 177; Nicolae Jorga, age., s. 167. Fındıklılı Mehmed Ağa’nın tuğların dikilmesine ilişkin verdiği tarih 21 Ocak 1683 iken; Râşid Efendi 6 Ağustos 1682, Dimitri Kantemir Hicri 1093 senesinin Şevval ayını kaydetmektedir. Bk. Râşid Mehmed Efendi-Çelebizâde İsmâil Âsım Efendi, age., s. 231; Dimitri Kantemir, age., s. 37.

61 Karl August Schimmer, age., s. 74. 
Çayırı denilen mevkide askerlerin sıkıntılarının hafifletilmesi için karargâh kurulması emredildi. Burada yaşanan bazı sel, kasırga ve benzeri iklim felaketleri başından beri sefere yanaşmayan şahıslar tarafindan birer propaganda ürünü olarak kullanılmıştır. Bir gece burada yaşanan korkunç bir firtınadan ve yağmurla karışık bir kasırgadan dolayı kimse yerinden hareket etmeye cesaret edememişti. Üstelik IV. Mehmed'in, Kara Mustafa Paşa'nın, diğer paşalar ile müftünün çadırları devrilerek kullanılamaz hale gelmişti. Çırpıcı Çayırı'nda yaşanan bu felaketlerden sonra karargâh Silivri yakınlarına taşınmış, ancak burada da kopan yeni bir firtına bu defa sadece çadırları değil, atları, yük arabalarını, hayvanları hatta askerleri bile sürükleyerek denize götürmüştü. Yaşanan bu felaketler askerler arasında bir memnuniyetsizliğe neden olmuştu. Başından beri bu seferin karşısında duranlar, bu hadiselerin ilahi bir öç olduğunu yüksek sesle dillendirmeye başlamışlardı. İleri gelen askerlerden bazıları Sadrazam'a, "Suyun gelişi yamandır. Hoyrat bahâdrrlı̆̆r fầide virmez. Belki hırka-i mübâreke ve sancak-ı şerîfe bir hatâ ola. Bari Dâvudpaşa Sarâyına yollayup kendünüz çiftliğinize teşrîf buyurun." demişlerse de buna, "Bunlan girü döndürmek uğur değildir." şeklinde karşlık veren Sadrazam'ı fikrinden döndürememişlerdir. Neticede bu seferi istemeyenlerin tüm şikâyetlerine karşın Sultan da Sadrazam ile birlikte bu olanlara kulak asmamış ve her ikisi de boş inanç olarak gördükleri bu söylentileri görmezden gelmişlerdi. ${ }^{62}$

Edirne'ye varan ve kış mevsimi boyunca gerekli sefer hazırlıklarını tamamlayan Osmanlı ordusu, 1683 Nisan’ının başında Sultan'la birlikte Edirne'den Belgrad'a doğru yola çıktı. ${ }^{63}$ Sultan IV. Mehmed'in orduya eşlik ederek Belgrad'a kadar gelmesi manevi bakımdan askerlere güç katıyordu; hatta düşman ordusu karşısında çekinmeyen askerler Viyana hükümetinin ittifak arayışlarını işittiklerinde "İsterse bütïn Hristiyanlık aleyhimizde ittifak etsin. Biz kimseden korkmaynz." diyorlard. ${ }^{64}$ Osmanlı ordusu 13 Mayıs 1683'te Belgrad'a ulaştı. Buraya kadar orduya eşlik eden Sultan IV. Mehmed Sadrazam'a hitaben, "Sancak-ı Şerîfi sana ve seni Bârî ta'âlâ’ya emânet eyledim. Hâfiz ve nâsimn olsun." diyerek mutlak komuta yetkisini ona devretmiş ve avlanmak üzere Belgrad'da kalmayı tercih etmişti. ${ }^{65}$

62 N. Karaçay Türkal, agt., s. 788-789; Dimitri Kantemir, Osmanl İmparatorluğunun Yükseliş ve Çöküş Tarihi, C 3, s. 37-38; Karl August Schimmer, The Sieges of Vienna by the Turks, s. 75.

63 N. Karaçay Türkal, agt., s. 795; Dimitri Kantemir, age., s. 38.

64 Ahmet Refik Altınay, age., s. 25.

65 Mehtap Yılmaz, Vekâyi'-i Beç, YYLT, Marmara Üniversitesi, Türkiyat Araştırmalar Enstitüsü, İstanbul 2006, s. 42; N. Karaçay Türkal, agt., s. 801-802; Dimitri Kantemir, age., s. 39; Nicolae Jorga, age., s. 167; Andrew Wheatcroft, Kapıdaki Düssman, Habsburglar ile Osmanhlarn Avrupa Mücadelesi, çev. 
Belgrad'da serdarlık devredildikten sonra cesaretle ölüme koşan askerlerden faydalanılabileceği düşüncesi hâsıl olmuşsa da Kara Mustafa Paşa'nın tutumu bu konuda bir memnuniyetsizliğe neden olmuştu. Nitekim ona, askerlerine Hristiyanlara karşı şiddetle savaşmaları için hediyeler veren Kanuni döneminde olduğu gibi, cömert bir şekilde hareket edilmesi tavsiye edilmekteydi. Ancak iddiaya göre, para tutkusu ağır basan Sadrazam askerlerin sefer sırasında ölebileceği ihtimalini de gözönünde bulundurarak buna yanaşmamış, dolayısıyla düzenlediği bu askerî harekâtta ilk hatasını gerçekleştirmişti. ${ }^{66}$ Sadrazam Sultan’ı Habsburglara karşı sefere ikna ettiği sıralarda hedef Yanıkkale ve Komoron kaleleriydi. Ordunun yürüyüşü esnasında Reisülküttâp Mustafa Efendi, Kara Mustafa Paşa’ya telkinlerde bulunarak bu kadar büyük bir orduyla Beç yani Viyana üzerine gidilmesini öneriyordu. Bu doğrultuda Sadrazam’a kimsenin sözünü dinlememesini, tek yetkilinin kendisi olduğunu ve dolayısıyla büyük Türk ordusu karşısında düşmanın kesin bir şekilde yenilgi alacaklarını şu sözlerle ifade ediyordu: "...mübârek ayağınızn tozuyla varalım bir baş dizginimizi tahtgâh-ı çasar olan Beç kal'asında çekelim. İnşấallâhü ta 'âlâ feth ü teshîri su içmek kadar gelmez. Bari memleket almış oluruz." Reisülküttâb’ın bu sözleri Kara Mustafa Paşa'nın sefer düşüncesine uygun düşüyordu. Ancak Merzifonlu'nun sefer yönündeki fikir değişikliği İstolni-Belgrad'da düzenlenen savaş meclisine kadar sır olarak kalmıştı. ${ }^{67}$

Bu arada, Kara Mustafa Paşa, kendisine daha önce Harp Divanı Başkanı Herman von Baden tarafindan gönderilen 11 Mayıs 1683 tarihli mektuba henüz yanıt vermemişti. Mektup İmparator Leopold'un barışı korumak amacıyla büyük çaba gösterdiğini, iki taraf arasındaki savaş durumunun kendisini büyük üzüntüye soktuğunu ifade ediyordu. Bununla beraber mektupta uluslararası hukuka göre elçi Kaprara'nın serbest bırakılması talep ediliyordu. Nihayet Sadrazam 7 Haziran'da elçiyle görüştü ve Hermann von Baden'e hitaben yazılmış mektubu ona teslim etti. Bu görüşmeden beş gün sonra Kaprara 12 Haziran'da Budin'e gitmek üzere hareket etti. Ona verilen mektup kırmızı atlastan bir kese içindeydi ve verilen cevap gurur ve haşmeti yansitiyordu. Mektupta Kaprara’nın să̆ salim serbest bırakılacağı, bununla birlikte aralarındaki sulha aykırı davranıldığı, barış talebine karşılık Osmanlı Devleti tarafınca öne sürülen isteklerin kabul edilmediği ve dost

Neşenur Domaniç, Doğan Kitap, İstanbul 2012, s. 129.

66 De La Croix, An account of the Turks wars with Poland, Muscory, and Hungary, çev. A. Chaves, London 1711, s. 172.

67 N. Karaçay Türkal, agt., s. 808. 
olmaya yaraşır bir tutum sergilenmediği vurgulanmıştı. Ezilenlere sahip çıkmanın ve kendisine sığınanları korumanın Osmanlı padişahının geleneğinden olduğunu belirten Sadrazam, mektubu "Bundan sonra Hâliki arzu semann iradeti aliyesinde olan suveri hayrü şer her ne ise zuhur eder." ifadeleriyle sonlandırarak işin serencamının yüce yaratıcının elinde olduğuna işaret etmişti. ${ }^{68}$

Serdar-1 ekrem ve sadrazam olan Kara Mustafa Paşa öncülüğünde Türk ordusu mükemmel bir disiplin altında 1683 Haziran başlarında Yanıkkale'ye doğru geldi. Macar kralı ilan edilen Tökeli İmre büyük bir maiyetle beraber Macar marşları çalan borazanlar eşliğinde Sadrazam’ı görmek üzere Türk karargâhına ulaştı. Macar Kralı bir kaç defa Sadrazam'ın eteğini öpmek zorunda kaldı ve oturması için bir iskemle verildi. Aralarında meşveret gerçekleşti. Bununla birlikte Kara Mustafa Paşa tüm Macar halkının kral tayin edilen Tökeli'ye tabi olması gerektiğini belirten beyannameler gönderdi. ${ }^{69}$ Uygulama açısından etkili olan bu yolla, belli zümrelerin ikna olduğu ve Osmanlı Devleti'ne tabi oldukları görülmektedir. ${ }^{70}$

Haziran ayında sefer hazırlıklarının devam ettiği sıralarda 27 Haziran'da İstolni-Belgrad'da bir harp meclisi toplandı. Söze önce Kara Mustafa Paşa başladı ve “...gerçi kasdrmız feth-i Yanık kal'asıyla Komaran kal'asıdır. Fazl-ı Hakk ile teshîri mümkin, lâkin kal'a almuş oluruz memleket değil. Murâdım inşẩallâh Beç'e gitmekdir. Ne dersiz?" diyerek asıl niyetini ortaya koydu. Viyana üzerine gidilmesini teklif etti. Ancak kimseden ses çıkmadı. Sefer hedefi olarak Viyana’ya yönelmek isteyen Kara Mustafa Paşa, bu düşüncesinin meclisteki diğer devlet adamları tarafindan da kabul edilmesini istemişti. Oysa Sadrazam bunu yapmak mecburiyetinde değildi; zira yanında Sultan'ın kendisine tam yetki verdiği hatt-ı hümayunu bulundurmaktaydı. Buna

Cevat Üstün, age. s. 29-30; John Stoye, age., s. 71.

69

N. Karaçay Türkal, agt., s. 810-811; Nicolae Jorga, age., s. 168; Ahmet Refik Altınay, age., s. 20. Macar halkını Osmanlı Devleti'ne itaate davet eden beyannamelerden birisi de Şopron ahalisine gönderilendir. Beyannamede, yeryüzünün padişahı olan Sultan IV. Mehmed'in himmetlerine sığınarak Tökeli İmre’ye itaat etmeleri ve Osmanlı Devleti’ne bağlı olmaları bildirilmişti. Böylelikle kendilerine, yakınlarına ve mallarına bir zarar gelmeden Padişah'ın himayesinde güven içerisinde yaşamaları vaat ediliyordu. Ancak itaat teklifinin reddedilmesi ve düşmana destek olunması hâlinde Sultan’ın öfkeli gazabına uğrayacakları yazıyordu. Bu duruma düşmemeleri için yüce Osmanlı Devleti'nin büyüklüğü sayesinde rahat ve huzurlu bir yaşam için itaate razı olmaları istendi. Halil Edhem, "Kara Mustafa Paşa’nın Şopron Şehri Ahalisine Beyannâmesi”, TOEM, III/15 (1328/1912), s. 924-937; Ahmet Refik Altınay, age., s. 28-29.

70 Kara Mustafa Paşa'nın bu talebi uzun sürmeden etkisini gösterdi. Macar ileri gelenlerinden Zirinoğlu, Rakoczioğlu ve Bakanoğlu Sadrazam’n eteğini öperek İslam padişahı IV. Mehmed'e kulluklarını bildirmişlerdi. Bk. N. Karaçay Türkal, agt., s. 840; Râşid Mehmed Efendi-Çelebizâde İsmâil Âsım Efendi, age., s. 236. 
rağmen istişare yoluyla paşaların sempatisini kazanarak onları ikna etmek ve emirlerini kolay bir şekilde yürütmek istiyordu. Bu doğrultuda Sarı Hüseyin Paşa'ya, "...ağzın bağgl mu, niye söylemezsin?" diye sorduğunda "...fermân sizden hizmet bizden..." yanıtını aldı. Meşveret Sadrazam'ın arzu ettiği gibi devam ederken Kırım Hanı söz aldı ve Sadrazam'ın bu fikrine karşı çıktı. Öncelikle Yanıkkale ve Komoron kalelerinin ele geçirilmesini, etrafa akınlar yapılmasını ve ardından Viyana üzerine gidilmesinin bir sonraki yıla bırakılmasını teklif etti. Aksi takdirde imparatorun müttefik aramakta zorlanmayacağını ifade ettiyse de Han'ın bu tavrı Sadrazam'ın pek hoşuna gitmedi ve onun düşmanlığını kazandı. ${ }^{71}$

Sadrazam, daha sonra bu meclise davet etmediği Budin Valisi Arnavud İbrahim Paşa ile görüş̧ü. Paşa'ya "Paşa baba Beç'e gidicek olduk, ne dersin?" şeklinde sorması üzerine aldığı yanıt Sadrazam’ı memnun etmedi. Nitekim İbrahim Paşa da Kırım Hanı gibi muhalif bir duruş sergiledi. ${ }^{72}$ Sadrazam'ın Viyana kuşatması fikrine katılmayanlardan birisi de Orta Macar Kralı olan Tökeli Imre’ydi. Sadrazam’a “Viyana'nın Hristiyan âleminin kalesi sayıldiğın " hatırlatan Tökeli de diğer muhalif paşalar gibi uzun uzadıya Viyana kuşatmasının ertelenmesi gerektiğini savunmuştu. ${ }^{73}$ Oysa Kara Mustafa Paşa açısından amacına mani olabilecek bu görüşler istenilen bir durum değildi. ${ }^{74}$ Tüm bu muhalif çabalar Sadrazam’ı fikrinden döndüremedi ve hedef Viyana kalesi olarak belirlendi. Aslında bu seferin kararı çoktan alınmıştı ve harp meclisindeki konuşmalar Kara Mustafa Paşa’nın öfkesinin karşı fikir beyan edenlerin üzerine çekilmesinden başka bir netice getirmedi. ${ }^{75}$

Osmanlı cenahında bunlar yaşanırken Avusturya tarafinda ise yıllar sonra yeniden

71 N. Karaçay Türkal, agt., s. 818-819; Mehtap Yılmaz, agt., s. 67; Râşid Mehmed Efendi-Çelebizâde İsmâil Âsım Efendi, age., s. 239-240; Dimitri Kantemir, age., s. 39.

72 İbrahim Paşa, Habsburgların diğer devletlerle mukayese edilmemesi gerektiğini, zor durumda kaldığında diğger milletlerden yardım alabileceğini ve bu nedenle önceliğin Yanıkkale ve Komoron olmasının makul olacağını savundu. Ancak Paşa’nın bu düşüncesine sinirlenen ve kulak asmayan Kara Mustafa Paşa “...azîmetime mâni' oluyor.” düşüncesiyle Paşa’ya memur olduğu görevine dönmesini emretti. Kara Mustafa Paşa ve Budin Valisi İbrahim Paşa arasındaki görüşmeler için bk. N. Karaçay Türkal, agt., s. 819-820. Kantemir'e göre, tüm bu muhalefete rağmen Sadrazam inadından dönmemiş; sözle birşey yapamayacağını görünce bütün yetkileri kendisine devreden Padişah'ın hatt-ı hümayununu çıarıp göstermiştir. Bunun üzerine fermanı gören paşalar boyun eğerek Sadrazam’ın emrini kabul etmek zorunda kalmışlardır. Dimitri Kantemir, age., s. 49.

73 Sadrazam ile Tökeli İmre arasında gerçekleşen konuşmalar için bk. Dimitri Kantemir, age., s. 4044.

74 Halil İnalcık, Devlet-i Aliyye, Osmanl İmparatorluğu Üzerine Araştırmalar-III, Türkiye İş Bankası Kültür Yayınları, İstanbul 2015, s. 191.

75 Johann W. Zinkeisen, age., s. 68. 
üzerlerine gelen Türk korkusu alevlenmeye başladı. İmparatorluk sarayını sarsan bu gelişmeler başta İmparator Leopold olmak üzere tüm halkı büyük endişe içerisinde bırakmıştı. Halkı saran bu korku, yani bu topraklarda yeniden yeşeren Türk imgesi daha XVI. yüzyıldan itibaren yerleşmişti. ${ }^{76}$ Silahdar Findıklılı Mehmed Ağa, o sıralar Kutsal Roma İmparatoru Leopold'un gözleri yaşlı bir şekilde hüzne boğulduğunu kaydediyordu. ${ }^{77}$ Görüldüğü üzere İmparator, dindaş olmalarına rağmen Macar ileri gelenlerinin itaatsizliklerinden yakınıyor, bu durumdan ne denli etkilendiğini ortaya koyuyordu.

Osmanlılar ile Avusturyalılar arasındaki gerilimi takip etmemize yardımcı olan diplomatik kayıtlar ve çağdaş eserler dışında bir propaganda aracı olarak dönemin basını da etkin rol oynamıştır. Nitekim Viyana, 1683'te Gazette yayınında en üretken şehirdi; tüm Avrupa gazeteleri, iki taraf arasında tırmanan gerilimi haftada bir bu basın yoluyla izledi. 15 Mart 1683 tarihli Viyana haber bülteninde, Mart ayındaki Türk savaş ilanına yer veriliyordu. Verilen haberde Kaprara'nın barış girişimlerine de değinilmişti. Onun tüm barış çabalarına karşın Türklerin kabul edilemez istekleri olduğu, dolayısıyla savaşa Türklerin sebebiyet verdikleri haber ediliyordu. Gerçekten de sefere karar veren Türkler bu doğrultuda Belgrad'a doğru yürümekteydi. Gazette'de Sultanın istediği her şeyi silah gücüyle elde edebilecek kadar güçlü olduğuna ve Sadrazam’ın sefere olan isteğine dikkat çekiliyordu. Kaprara barış umutlarının ortadan kalktığını bildiriyordu. Böylelikle bültende yer alan haberlerin amacı, halkın dikkatini Avrupa'nın doğu cephesine çekmekti. ${ }^{78}$

76 Söz konusu Türk korkusunun XVI. yüzyıldan sonra oluşmasındaki başlıca faktör Osmanlı Devleti'nin Habsburg topraklarını tehdit etmeye başlamasıydı. Türkler tarihî resimlere, freskoya, dua kitaplarına, kroniklere, risalelere, şarkı ve efsanelere konu edilmişti. Halka yansıtılan imaja göre, Türkler kadınlar ve yavrularını keyif için öldürmekteydi. Martin Luther'in Türcken Propheceyung başlıklı eserinde bu görüşü destekleyen örnekler verilmiştir. Dönemin yazarlarına göre, dinî mekânlara saygı göstermeyen Türkler, kiliseleri ahır olarak kullanan, Meryem Ana resimlerine ok atan, kutsallarına söz eden günahkârlar ve sert savaşçılardı. Bu sebeple Türklere esir düşmek büyük şanssızlıktı. Bk. Bozkurt Güvenç, Türk Kimliği: Kültür Tarihinin Kaynaklan, 3. Basım, Remzi Kitabevi, İstanbul 1995, s. 295.

77 Imparator bu halde iken İspanya Kralı’nın kızı olan eşi Margaret Theresa, “Bu hüzn-i elemine sebeb nedir?" diye sormuş, ondan "Acebdir ki, Osmanlu pâdişâhı zîr-i destinde olan beğlerin birer nâme ile sefere da vet buyursalar, akabince emrine râm olup gelürler ve ne işe kullansalar cân u başlaryyla çalı̧̧urlar. Ammâ ben kendü re'âyâm olan Macar beğlerine âdem gönderüp da'vet eylerim, aslâ itâ'at idüp gelmezler.” cevabını almıştı. N. Karaçay Türkal, agt., s. 834-835.

78 Stéphane Haffemayer, "Public and Secret Networks of News: The Declaration of War of the Turks against the Empire in 1683", in the News Networks in Early Modern Europe, Ed. Joad Raymond, Noah Moxham, Brill, Leiden\&Boston 2016, s. 805; 808-809; 819. 
O zamanlar Avrupa'daki Türk imajı bölgedeki diğger unsurları da etkilemişti. Macarların imajı Tökeli İmre’nin Osmanlı ittifakı nedeniyle gittikçe kötü bir hale gelmişti. ${ }^{79}$ Onun ittifak çabaları sonucunda Protestan Macarlar, daha önce Polonya-Litvanya'da sahip oldukları olumsuz imajı düzeltememiş; aksine bu durum daha da pekişmişti. Başka bir ifade ile ondan önce Rákóczi’nin Polonya’ya karş1 yürüttüğü savaş sırasında Macarlara ve Transilvanyalılara karşı ortaya çıkan olumsuz tutum daha da güçlenmişti. Macarlar, 1680'lerden kalma elyazması gazetelerde klişeleşmiş bir figür olarak "Hain", "İsyancı" damgası yemiş ve bu durum uzun zaman Polonya folklorunda hayatta kalmıştı. ${ }^{80}$ Bundan sonra Tökeli'nin itibarını bertaraf etme arzusu onun imparatorluk propagandasında ayrıntılı bir şekilde tanımlanmasını gerektirdi. Bununla ilgili olarak 1681-1682'de kariyerinin zirvesinde iken siyasi ve askerî faaliyetleriyle ilgili önemli miktarda basılı bilgi ortaya çıkmıştı. Tökeli'nin atlı portreleriyle resimlenen broşürler, onun yetiştirilmesi, aile geçmişi, ekonomik ve askerî güçleri ile kontrolündeki kaleler vurgulanmıştı. Gerçekten de, Regensburg'daki imparatorluk diyetine getirilen el yazması gazeteler, onun artan siyasi ve askerî öneminin altını çiziyordu. ${ }^{81}$ Böylece Katolik Hristiyan dünyasına muhalif olarak nitelendirelen Imre Tökeli, Habsburgların propaganda faaliyetlerinin önemli bir unsuru haline gelmişti.

1683 yılı Haziran ayı boyunca, Estergon veya Uyvar'da Habsburg ordusunun başarılı olduklarına ilişkin bir haber alınamamış; bunun aksine, Türklerin Macaristan'da ilerlemeye devam ettiklerine dair umutsuz raporlar gelmişti. Bu sebeple gün geçtikçe Viyana'da hüküm süren Türk korkusu artmaya devam etmişti. Sürekli

79 1680'lerde uluslararası çevrelerde en itibarlı Macar, askerî arenada kral ve imparatorluk sarayı ile işbirliği yapan yüksek rütbelilerden veya soylulardan bir kişi değildi. Bu kişi hükümdarın rakibi olan ve bu dönemde büyük bir itibara sahip İmre Tökeli’ydi. Zira dönemin anlayışına uygun hareket etmeyen Tökeli, Osmanlılarla ittifak lehine hareket eden siyasi bir figür oldu. 1683'te Viyana Kuşatması'na kadar, Protestan Alman eyaletlerinde Tökeli, dinî özgürlüğü ve Macaristan'daki Protestan kasabaların çıkarlarını savunan bir adam olarak görülüyordu. Buna karşılık, imparatorluk ve Papalık propagandasında ise alay ve hiciv konusuydu. Böyle bir propagandada, Tökeli’nin sahip olduğu kale ve kasabaların ele geçirilmesi, Osmanlıların sahip olduğu yerlerin yeniden ele geçirilmesi kadar önem kazanmıştı. Nóra G. Etényi, "The Genesis And Metamorphosis Of Images Of Hungary in The Holy Roman Empire", in A Divided Hungary in Europe: Exchanges, Networks and Represantations, 1541-1699, Vol. III, ed. Gábor Almási, Szymon Brzezinski, Ildikó Horn, Kees Teszelszky, Áron Zarnóczki, Cambridge Scholars Publishing, 2014, s. 39.

80 Szymon Brzeziński, "Forms And Functions of the Image of Hungary in Poland-Lithuania", in A Divided Hungary in Europe: Exchanges, Networks and Represantations, 1541-1699, Vol. III, ed. Gábor Almási, Szymon Brzezinski, Ildikó Horn, Kees Teszelszky, Áron Zarnóczki, Cambridge Scholars Publishing, 2014, s. 80.

81 Nóra G. Etényi, agm., s. 40. 
ayinler gerçekleştiriliyor, Viyana halkının moralinin iyileştirilmesine çalışlıyordu. Hatta çıkarılan resmî emirden sonra bütün esnaf ve meslek sahiplerinin haftada bir saat St. Stephen Katedrali'nde gerçekleştirilen ayinlerde yer almaları istendi. Bizzat Leopold pazar günleri sabah yapılan ayinlere iştirak etti. Yine resmî emirle birlikte eski çanlar tamir edilerek işler hale getirildi ki bunlara "Türk Çanlarn" yani "Türkenglocken" deniyordu. Başta Viyana'da olmak üzere memleketin her tarafinda her sabah çanlar çalınmaya başlıyor ve halk devamlı olarak Türklerden kurtulmak için dua etmeye çağrıliyordu. ${ }^{82}$

İmparatorluğun barış elçisi Kaprara’nın Türklerin seferden vazgeçmeyecekleri yönünde ilettiği karamsar haberler, Viyana'daki korku iklimini üst düzeye çıkarmıştı. Osmanlılara karşı tek başına direnemeyeceğini anlayan İmparator Leopold kendisine müttefik aramak zorunda kald ${ }_{.}{ }^{83}$ Imparatorluk için Papalık'tan gelecek maddi-manevi destek, Kuzey İtalya ve Frankoniyen Almanya'da bulunan genç asilzadelerin gönüllü yardımları, Bavyera ve Saksonya prensliklerinde asker toplanması ciddi önem taşımaktaydı ${ }^{84}$ Bu doğrultuda İmparator Leopold, Brandenburg, Saksonya ve Bavyera prenslerine, Frankoniyen ve Suap meclislerine, Venedik Cumhuriyeti’ne, Polonya Krallığına, İspanya'ya, Papa'ya ve Hollanda'ya ittifak maksadıyla elçiler gönderdi. ${ }^{85}$

İttifak girişimleri devam ederken Brandenburg Elektörü Frederick William, Fransız Kral XIV. Lui'nin isteklerinin Almanya tarafindan kabul edilmediği sürece Osmanlılara karşı bir ittifakın içerisine dâhil olmayacağını bildirdi. Zira doğrudan bir Türk tehlikesi Brandenburg Prensi tarafindan dikkate değer bir boyutta değildi. Bununla birlikte, imparatorluk yetkilileri bu ittifak için büyük öneme sahip başka antlaşmalar gerçekleştirdiler. Mesela İmparator'a damat olmak isteyen ve Tuna ile Inn'de Habsburg lordluk payesi elde etmeyi arzulayan Bavyera Prensi

82 John Stoye, age., s. 182.

83 Yukarı Macaristan'dan, Tökeli İmre'nin 15 Mayıs'ta güçlü bir orduyla yürüyüşe başlayacağı haberi üzerine İmparator, bakanlarına, bu kadar güçlü ve korkunç düşmanlara karşı yüzleşmeye hazır olmaları için çabalarını iki katına çıkarma emri verdi. Bk. Stéphane Haffemayer, agm., s. 809.

84 Alan Palmer, Osmanl İmparatorluğu Son Ü̧̧̧ Yüz Yil Bir Çökü̈sün Yeni Tarihi, (Çev. B. Çorakçı Dişbudak), Sabah Kitapları, İstanbul, 1992, s. 23.

85 Cevat Üstün, age., s. 32. Onun bu ittifak çağrısına karşılık Fransa, Habsburglara doğrudan destek vermese de Papalık aracılığıyla onlarla savaşa ara vererek dolaylı bir şekilde yardımcı oldu. Bu durum, bir anlamda "Hristiyan Birliğ̨̌" zihniyetinin sürdüğünü gözler önüne serdi. Selim Hilmi Özkan, "XVII. Yüzyılın Sonlarında Hıristiyan Birliği Projesi ve Osmanlı-Fransız Illişkileri”, $S D \ddot{U}$ Fen Edebiyat Fakültesi Sosyal Bilimler Dergisi, Mayıs 2009, S. :19, s. 65. 
Max Emmanuel 11.000’den fazla asker gönderme sözü verdi. Bavyera Prensi’nin bu yardım vaadine karşılık, Saksonya Prensi'nin ikna edilmesi kolay olmadı. Saksonya Elektörü III. Johann George vereceği herhangi bir desteğe karşılık Saksonya ve Bohemya sınırları üzerinde anlaşmazlığa sebep olan bazı toprakların kendisine terk edilmesini şart koştu. Müttefik bulmakta zorlanan Imparator Leopold bu istekleri değerlendirmek zorunda kaldı; hatta prensi ikna etmesi için Saksonya Ekonomi Bakanı Gerstorff'a rüşvet bile verdi. Sonuçta yapılan antlaşmaya göre Saksonya 11.400 kişilik bir askerî birlik göndermeyi taahhüt etti. Keza Frankoniyen ve Suap meclisleri de Türklere karşı imparatorluğa destek vaadinde bulundular. Venedik kendi topraklarından asker toplanmasına izin verirken Papalığın çağrısına kulak veren İspanya ve İtalya da savaşı finanse edebilecek önemli maddi destekte bulundular. Hollanda ile yapılan ittifak görüşmelerinden ise tatmin edici bir sonuç çıkmadı. ${ }^{86}$

Bunlardan başka ittifak kurulabilecek devletlerin başında Lehistan gelmekteydi. Ne var ki, bir müddet önce 1681'de imzalanan Osmanlı-Rus antlaşması Lehistan açısından da olası bir Türk tehlikesini ortaya çıkarmıştı. Bu nedenle Lehistan Kralı Jan Sobieski Avrupa'nın her yerine mektuplar yollayarak Türk karşıtı söylemlerle Kutsal İttifak oluşturmaya çalışmıştı. Sobieski, elçileri aracılığıyla yolladığ1 propaganda içerikli mektuplarında Hristiyan yöneticilere, "Barbarlarn fetihlerine fetihle, zaferlerine zaferle karşılı vermeyi, onlar Avrupa'ya geldikleri steplere geri göndermeyi öneriyorum, tabii ki, yalnızca zafer kazanmay ve canavarn ehlilestirmeyi amaçlamyorum, ayn zamanda Bizans kalıntılarndan çıkarak bu canavan çöle kovmay da öneriyorum." sözleriyle sesleniyordu. Ancak o dönemde Batılı devletler Türklerle savaş istemiyordu, üstelik Viyana hükümeti Türklerin Lehistan ile olası bir savaşa girmesini memnuniyetle karşllyordu. Nitekim bu şekilde Türk tehlikesinin kendi topraklarından uzaklaşacağını düşünen İmparator ilk başlarda Lehistan ile müttefik olmak için yavaş bile davranmıştı. ${ }^{87}$ Fakat artık durum ciddiydi ve Osmanlılar Viyana kapılarına dayanmak için harekete geçmişti. Zira elçi Kaprara, Leopold’a yazdığg bir mektubunda "Türklere karşı monarşiyi ve bütün hıristiyanlı̆̆ korumak için Majestelerinin kılıca sarlmaktan başka yapacaklan bir şey kalmamıştır. Barıs umutlan ortadan kalktı.” demişti. Keza Hermann von Baden’e gönderdiği bir mektubunda da Osmanlı hükümetinin ileri sürdüğü kabul edilemez istekleri belirttikten sonra "Sonunda, bütün bu iş

86 John Stoye, age., s. 144; Cevat Üstün, age., s. 32-33; Andrew Wheatcroft, age., s. 190.

87 Sabire Arık, Polonya Kralı III. Jan Sobieski ve Hükümdarlığında Osmanlı Lehistan İlişkileri (1674-1696), YDT, Ankara Üniversitesi Sosyal Bilimler Enstitüsü, Ankara 2004, s. 136. 
muhakkak harbe dayanacaktr." diye ekliyordu.$^{88}$ Gerçekten de Sadrazam türlü yollarla Padişah'ı ve önemli gördüğü kişileri bu sefere ikna etmiş, Imparator'a barış yollarını kapatmıştı. Öyle ki Sadrazam Habsburgların batıda XIV. Lui tarafindan tehdit edildiğini de biliyordu. Ayrıca Kaprara'nın bu denli barış isteklerinden Habsburgların zayıf düş̧ügüne kanaat getiriyor, dolayısıyla bu savaşın başarı şansına olan inanc1 gitgide güçleniyordu. ${ }^{89}$

Iyi bilindiği üzere, Osmanlılar ile Habsburglar arasındaki savaşlar hem dünyevi iktidar savaşları hem de din savaşları olarak görülüyordu. Bununla birlikte, kiliselerin kutsiyetinin ayaklar altına alınmasına dair hikâyeler daima iyi ürün veriyordu. ${ }^{90}$ Habsburglar ile Lehistan yakınlaşmasında asıl baş âmil Merzifonlu Kara Mustafa Paşa olmuştu. Onun savaşa dair ısrarı ve Viyana üzerine yürüme fikrini hemen açıklamaması her iki tarafı aynı ölçüde telaşa sürükledi. ${ }^{91}$ Bu nedenle, durumu değerlendirmek isteyen Papa XI. Innocentius kendi öncülügünde Hristiyan devletlere birlik olma çağrısında bulundu. ${ }^{92}$ Papa'nın bu çağrısına en sıcak bakan Leh kral Jan Sobieski'ydi. ${ }^{93}$ Ancak Sobieski'nin bu ittifakı gerçekleştirmesi kolay olmamıstı.

Zira Fransa, Lehistan’ın Habsburglarla olası bir ittifak düşüncesine karşı çıkmaktaydı. ${ }^{94}$ Leh Kralı'nın planlarını alt üst etmek için Fransa yanlısı nüfuzlu kimseler ile Varşova'daki Fransız elçi Markiz de Vitry, Sobieski’nin ittifak girişimlerine kar-

Sauer, Rom Und Wien Im Jahre 1683: Ausgewählte Actenstücke Aus Römischen Archiven Zur II. Säcularfeier Der Befreiung Wiens Als Festgabe Des Unter Allerhöchstem Protectorate Stehenden Priestercollegiums Von Campo Santo Zu Rom, K. K. Hof- und Staatsdruckrei, Wien 1883.

93 Defterdâr Sarı Mehmed Paşa, Zübde-i Vekayiât adlı eserinde Sobieski'den bahsederken onun daha önce yalandan dost görünerek Osmanlı Devleti'yle barış antlaşması imzaladığını, ancak daha önce Lehistan’ın kaybettiği topraklar olan Kamaniçe, Podolya ve Ukrayna'nın içine dert olduğunu ve bu sebeple ilk firsatta barış antlaşmasını bozarak Avusturya imparatoruna yardımına koşan hain biri olarak kaydetmiştir. Bk. Defterdar Sarı Mehmed Paşa, Zübde-i Vekayiât, haz. Abdülkadir Özcan, Türk Tarih Kurumu Yayınları, 1985, s. 158.

94 Daha evvel İmparator ile Lehistan Kralı arasında müzakereler gerçekleşmiş ve bir mutabakata varılmıştı. Fakat bu görüş birliğinden sonra artık her iki sarayın Lehistan Diyet Meclisi'ni çeşitli yollarla ikna etmesi gerekiyordu; çünkü Lehistan hükümetinin imzaladığı bir antlaşma, Diyet Meclisi’nce kabul edilmedikçe geçersiz sayılmaktaydı. John Stoye, age., s. 153. 
Ş1 yeni entrikalar çevirmeye başladılar. Mecliste başlayan tartışmalar ittifakı zedeleyecek nitelikte görünüyordu. O sıralar meclisteki işinin zorluğunu kavrayan Kral Sobieski, karşısında duranlara "Bildiğimiz gibi Türkler hazırlanıyor. Eğer Viyana giderse, Varşova'y kim koruyacak?” diyerek izlediği siyaseti ortaya koymaya çalışıyordu. ${ }^{95}$ Buna karşılık Fransız elçinin en büyük dostu olan Lehistan Hazine Bakanı Andreas Morsztyn, ittifaka muhalif birisi olarak hükümetin bütün görüşmelerini ve kararlarını şifreli mektuplarla Fransa'ya yollayarak kurulan entrikalara destek veriyordu. Muhaliflere karşı Sobieski’nin yegâne yardımcıları ise Papalık elçisi Pallavicini ile beraber Waldstein ve Habsburg daimi elçisi Zierowski’ydi. ${ }^{96}$

Morsztyn'le birlikte bulunan muhalifler neredeyse her meclis toplantısını engelliyor; ittifak antlaşmasının imzalanmasını onaylamadıkları gibi Habsburglara yönelik katı bir siyaset takip ediyordu. Bu doğrultuda yapılan propaganda çalışmaları sonuç veren bir görüntüdeydi. Nitekim dağıtılan bir broşürde "Kendi krallarrmız olarak hiçbir zaman Avusturya kanı taşıyan bir prens istemedik. Bu gün için Hirvatistan, Moravya ve Macaristan'da olduğu gibi, bizim de bir gün onlarn (Avusturya'nın) boyunduruğu altna girme ihtimalinden korunmamız için silahlarmııı kuşanmamız gerekiyor. Gerçekte Türkler fetihlerini Tuna'ya doğru ilerletiyorlar. Bize göre önemli olan; iki ynl önce, biz zor durumda iken, Sezar savaşın bizi vurmasın bekliyordu, bize yardıma geldi mi?" denilerek hükümetin politikası sert bir dille eleştiriliyordu. ${ }^{97}$ Fakat sıradan bir kral olmadığını gösteren Sobieski izlediği başarılı siyasetle Diyet Meclisi'ndeki muhalif görüşü ikna etti ve Polonya-Avusturya ittifağına karşı direniş kırılmış oldu. ${ }^{98}$

95 Sabire Arrk, agt., s. 136-137.

96 Cevat Üstün, age., s. 34; John Stoye, age., s. 153.

97 Sabire Arık, agt., s. 138.

98 Kral Sobieski, karşısında kendisine engel olmak isteyen bir çoğunluğun farkındaydı. Yaklaşmakta olan parlamento mücadelesi için Polonya'nın hükümdarı alışılmadık derecede iyi keskinleşmiş bir çağdaş diplomasi aracı kullandı: posta karşıtı casusluk. Polonyalılar ve Avusturyalılar, de Vitry'nin raporlarını Paris'e ulaşmadan önce okuma firsatı buldu. Dolayısıyla bu durum, Sobieski'nin Diyet Meclisi toplanmadan önce kamuoyunu aldatan hileleri için önemli kozlarından biri oldu. Bunun dışında da gelişmeler vardı. Morsztyn ve de Vitry’nin çabalarıyla, bazı soylularla gizli bir akşam yemeği tertip edildi. Yemeğe katılan Polonyalılar Fransa'yı desteklemeyi kabul ettiler. Bunun karşılığında yemeğe katılanlardan Jablonowski, gelecek bir zamanda Lui'den Polonya tahtı için destek alacaktı. Bu gelişmeler Sobieski’nin yeni girişimlerde bulunmasına sebep oldu. Paris'e gönderilmek istenen raporlar ele geçirildi ve bunların mecliste okunması sağlandı. Morsztyn hain ilan edildi. Sobieski kendisine muhalif olan kesimden adamları saf dışı bıraktı ve sonra onları affederek kazanmaya çalıştı. Böylelikle büyük Polonyalı aristokratların Polonya-Avusturya ittifağına karşı direnişi kırılmış oldu. Bk. Thomas M. Barker, age., s. 157-158; Cevat Üstün, age., s. 35; Sabire Arık, agt., s. 139. 
Habsburg-Lehistan ittifakının başarılı bir şekilde oluşturulması büyük ölçüde Sobieski'nin dikkatli planlamasından kaynaklanmış gibi görünse de, Papa’nın elçisi Pallavicini'nin gayretlerinden hareketle Kilise'nin de önemli katkıları olmuştu. Zira Papalık elçisi Pallavicini, bir ittifak yanlısı olarak, müzakerelerin başarılı geçmesi için önemli adımlar attı. Papa XI. Innocentius ona ittifakı sağlamak üzere Kilise gelirlerini tahsis etmişti. ${ }^{99}$ Üç ay süren görüşmelerden sonra, Lehistan Kralı Sobieski ile Papalık'ın himayesinde nihayet Osmanlı Devleti’ne karşı 31 Mart’ta imzalanan ve İmparator tarafindan 2 Mayıs'ta tasdik edilen resmî bir işgal ve savunma ittifakı oluşturuldu. ${ }^{100}$ İki devlet arasında akdedilen bu ittifak anlaşması bilhassa Viyana için son derece mühimdi. Zira daha önce 1682 sonlarında başlatılan birtakım girişimler başarısızlıkla sonuçlanmıştı. ${ }^{101} \mathrm{Bu}$ sebeple antlaşmanın onaylandığı haberi Viyana'da büyük bir sevinç uyandırdı. Alman kronikçi Brülig bu sevinci şöyle not etmişti: "İşte çok ağır bir firtınadan sonra güneşin ilk ışılan parladı ve beklenilmedik şekilde üzüntü mutluluğa dönüştü, çünkü uzun zamandan beri beklenen ittifak antlaşmasının imzalandı̆̆ haberi Varşova'dan geldi" ${ }^{102}$

Vatikan'ın izlediği yoğun diplomasi neticesinde mevcut Türk tehlikesine karşı yürütülen propaganda kampanyaları geçmişteki uygulamalara nazaran daha etkili oldu. ${ }^{103}$ Öyle ki XVII. yüzyılın sonlarına gelindiğinde Osmanlılara karşı ittifak

99 Thomas M. Barker, age., s. 158.

100 Antlaşmaya göre, İmparator Leopold 60 bin ve Kral Sobieski 40 bin asker sağlayacak ve ayrıca İmparator, birliklerin ilk donanımı için Kral'a en kısa zamanda 100 bin taler ödeyecekti. Antlaşmanın esas hedefi, Viyana veya Krakow'un Türkler tarafindan kuşatılması durumunda, anlaşmada karara varıldığı üzere her iki devlet tüm kuvvetleriyle birbirlerine yardım edecekti. Bk. Johann W. Zinkeisen, age., s. 72.

101 Yurtiçinde bu hazırlıklar sürerken dışarıda da bazı saraylar nezdinde, Leopold'un durumunu sağlamlaştırmak için devamlı olarak diplomatik girişimlerde bulunuldu. Yapılan kimi görüşmeler tam bir hayal kırıklığıyla sonuçlandı. 17 Kasım 1682'de Waldendorf ismindeki bir elçiye önce Renanya ardından Palatine elektörleriyle müzakerelerde bulunması emredildi. Elçiden yapılması istenen şey, ilkbahar başlarında Regensburg Diyet’inde bir araya gelmek suretiyle, olası bir Türk saldırısına karşı bu elektörler ile İmparator’un ortak savunma meselesini görüşmekti. Ancak Aralık ile Ocak aylarında Cologne, Ehrenbreitstein, Mainz ve Heidelberg’i ziyaret eden elçi, muhataplarının hiçbirisinin Viyana'nın taleplerini onaylamaya hazır bulunmadıklarını gördü. Ayrıca bu memleketlerin hükümdarları Fransa kralı Lui'den de oldukça fazla korkuyorlardı. Bk. John Stoye, age, s. 143.

102 Sabire Arık, agt., s. 140.

103 Osmanlıların Avrupa'dan sınır dışı edilmesini amaçlayan Papalık politikası, XVI-XVII. yüzyılların Avrupa siyasi süreçleriyle daha az uyumluydu. Avrupa monarşilerinin iç krizleri ve onların yeniden canlanmasının yanı sıra iktidarların siyasi hedefleri, Avrupa'da Osmanlı karşıtı bir ittifak olasılı̆̆ını önemli ölçüde güç kılıyordu. Zira söz konusu yüzyıllarda, Kutsal Makam’ın temsilcileri olarak Papaların genel siyasi politikalarına bakıldığında Osmanlı meselesine yönelik tümüyle aynı 
fikrinin en hararetli savunucularından biri Katolik dünyasının en büyük temsilcisi Papa XI. Innocentius olmuştu. Papa, Hristiyan hükümdarlara gönderdiği mektuplarda durmadan Türk karşıtı bir propagandayı yaygınlaştırmak için uğraş vermekteydi. Belki de onun Osmanlılara karşı bir savaşa çağrıda bulunması izlediği propaganda sürecinin en önemlisiydi. Osmanlı tebaasından olup 1683 Viyana Kuşatması'nda esir düşen ve daha sonra kurtulan Hasan Esirî ismindeki birisi Papa'nın papazları aracılığıyla gönderdiği mektubu eserinde kaydetmektedir. Buna göre din düşmanı olan Türkler çok sayıda kana susamış askeriyle Viyana kalesini kuşatıp, etrafını yakıp yıkarak yağmada bulunmaktaydı. Çık sayıda kimseyi katletmeye devam ediyordu. Kadınların ve kucaklarında bulunan masum yavruların canlarını alıp, genç kadın, kız ve oğlanları esir ederek hizmetlerinde kullanmak istiyorlardı. Bu nedenle, bu ateşi söndürmek, saldırı selini engellemek, Viyana kalesini ve esirleri kurtarmak bütün Hristiyanlara farz olmuştu. Bu doğrultuda tüm dindaşların bu uğurda can ve mal ile gereken tüm desteği vermeleri isteniyordu. Ĕ̆ger ihmal edilip müsamaha gösterilecek olursa bu ateşin herkesi saracağı muhakkaktı. Herkesin yemesinden içmesinden ödün vermesi, eşlerin kadınlarının yanına varmaması, gerekirse kadınların çocuklarına meme vermemesi, koyunları kuzusundan ve sığırları buzağılarından ayırarak her gün gece-gündüz ağlayarak dua etmesi talep ediliyordu. Yüce Tanrı Hristiyan askerlerine kuvvet ve yardım verip Türk belasını bu kullarının üzerinden ancak bu şekilde kovabilirdi. Papa'nın deyimiyle, Türkler Tanrı'nın gazabından meydana gelmiş bir kavimdi ve bunların kalplerinde merhamet ve incelik yoktu. Âdetleri, vardıkları memleketi yakıp yıkarak kiliseleri harap etmekti. Ateş gibi yakan ve sel gibi yıkan bu kan içiciler evlatları anne babalarından ayıran kalpsiz bir kavimdi. Türklerin vardığı yerde bir daha ateş yanmaz, tütün tütmez, ot bitmez ve horoz ötmezdi. Eğer bu konuda ihmalkâr davranılırsa aynı sonla herkes karşılaşabilirdi. Şimdi bu hususta her kim yardım eder ve İsa ile Meryem’in dini uğrunda gayret gösterirse öldüklerinde doğrudan cennete gitmesi için kendisi kefil olacaktı, bunun sözünü veriyordu. Kiliselerde okunan bu mektuplardan sonra tüm rical ve halk etkilenerek coşkuyla işe koyulmaya başlamışlardı. Birçok kimse Türk belasının kendilerinden uzaklaşması halinde belli miktarlarda mallarını kiliseye hibe edeceklerini dahi belirtmişlerdi. ${ }^{104}$

fikri temsil etmedikleri görülmektedir. Hatta yüzyıllık Habsburg-Fransız çatışmasında, daha sonra Otuz Yıl Savaşı'nda Fransız tarafını alan Papalar, açıkça Osmanlı karşııı mücadeleye Kilise'nin Habsburg yanlısı başkanlarından daha az bağlıydı. Antal Molnár, "Relations between the Holy See and Hungary during the Ottoman Domination of the Country", in Fight Against the Turk in Central Europe in the First Half of the 16th Century, ed. István Zombori, Budapest 2004, s. 202.

104 Göker İnan, agt., s. 1387-1388. 
Bununla birlikte siyasi irade ve propaganda bakımından üst sinıflardan verilen destekler de önemli bir kaynak sağlamaktaydı. Türklere yönelik bir kara propaganda olmadan toplum içerisinde bir birlik oluşmayacağı ve silahlı kuvvetlere malî gelir sağlanamayacağı düşüncesi de hâkimdi. ${ }^{105}$

Tarih boyunca olduğu gibi, bu hadisede de vaizler sıkı bir propaganda faaliyetinin içerisinde olmuşlardır. Viyana'da halkın desteğini almak için insanların sempatisini kazanmış bazı vaizler, Tanrı'nın kendilerine ders verme ihtiyacı duyduğunu, bu sebeple de halka müslümanları ve onların zalimliklerini yolladıklarını yüksek sesle söylüyorlardı. Bununla birlikte, "Sancta Clara" yani "Kardeşler Cemiyeti Üyesi" vaiz Abraham matbaaya basılmak üzere verdiği eserinin ismini "Ey Hristiyanlar, uyann, uyanın!" koymuştu. $\mathrm{O}$ bu eseriyle, insanları gaddar ama korkak diye tanımladığı düşmana karşı cesurca mücadele etmeye çağırıyordu. Hatta Abraham, kuşatmanın arifesinde insanların yanıt aradığı "Türk nedir?" sorusuna karşllı verenlerin başında gelmekteydi. Ona kalırsa Türklerin kim olduğu sorusuna en iyi yanıtı ancak Hristiyanlar verebilirdi. Buna göre Türk, kısaca Hristiyan karşıtı, kibirli, açgözlü kaplan ve iflah olmaz şeytandı. Aynı zamanda dünyayı tahakküm altına almak isteyen bu kavim çok gaddar, doymak bilmeyen ve merhametsiz bir topluluktu. ${ }^{106}$ Türklerden kurtulmak ümidiyle, Kilise yönetimi tarafindan 27 Haziran'dan 3 Temmuz'a dek tüm hafta Tanrı'nın Hristiyanlara destek olması için geniş çaphı dinî ayinler düzenlendi. ${ }^{107}$

Türklerin Avrupa'nın kalbine doğru ilerlediği haberleri geldikçe başta İmparator olmak üzere Hristiyanlar büyük bir paniğe kapılmıştı. Türklerin Yanıkkale'yi bırakıp Viyana üzerine yürüdüğü haberleri dehşet vericiydi. Yanıkkale komutanı gönderdiği haberde "Eğer Türk askeri ahvâlinden suâl olunur ise gökde olan ylldzzlar gibi hadd ü hisâbr yokdur." diyerek önlerinde hiçbir engelle karşlaşmadan Viyana'ya yürüyüşün sürdügünü bildirmekteydi. ${ }^{108}$ Özellikle Imparator, Petronel önlerindeki

$105 \mathrm{Bu}$ doğrultuda, Türk vergisi isminde bir gelir elde etmek için Türklere dair bilgilerin yayılması sağlanıyor, böylelikle insanların motive edilmesi amaçlanıyordu. Bu noktada Türklerle ilgili ve savaşın gidişatına dair sunulan bilgilerle aldatıcı ve basmakalıp resimler serpiştirilmiş bir şekilde halka arz ediliyordu. Zira elde edilen bu gelirlerin nerelerde harcanacağı konusunda insanlara ne yapıldığı ve ne yapılacağı hususunda halkı heveslendirme ihtiyacı vardı. Karl Vocelka, "Erken Yeniçağda Hristiyan Batı Dünyasında Türk Imajı”, çev. Songül Çolak-Fatma Akay-Türker, Gaziosmanpaşa Üniversitesi Sosyal Bilimler Araştırmalan Dergisi, 11/2, (Kış 2016), s. 250.

106 Lynne Tatlock, "Selling Turks: Eberhard Werner Happel's Turcica (1683-1690)", Colloquia Germanica, Vol. 28, No. 3/4 (1995), s. 307.

107 John Stoye, age., s. 182-183.

108 Göker İnan, agt., s. 1387. 
yenilgi haberi üzerine, uzun bir müddet yaşadığı kararsızlı̆̆ına son verdi. Leopold, 7 Temmuz'da saray ileri gelenleriyle birlikte şehirden firar etmek için hazırlanıyor, kalenin kumandanlığını ise basiretiyle tanınan ve çok deneyimli bir komutan olan Kont von Starhemberg'e devrediyordu. Orduların kumandasını ise eniştesi olan ve daha önce Lehistan tahtına aday gösterdiği Charles de Lorraine'e bırakmıstt. Viyana'dan 60 saat uzaklıktaki Lintz'e çekilen İmparator, buradan desteklerini almak üzere tüm komşu prenslere mektuplar yolluyordu. Fakat onun Viyana'dan ayrılması kentteki hoşnutsuzluğu artırdı. Her zümreden binlerce insan kaçış yolları ararken ağıtlar yakmaya devam ediyordu. Söylentilere göre yarım günde 60 bin insan şehri terk etmişti. ${ }^{109}$ İmparator'un beraberinde bulunan Fransız elçi Marquis de Sébeville Fransa kralı XIV. Lui’ye yazdığı 14 Temmuz 1683 tarihli yazısında Viyana hükümdarının ayrılışını ve bunun Viyanalılara nasıl yansıdığını şöyle kaydetmiştir: "Biz Viyana'dan çıkarken burjuvalar bağrnyorlard. Imparator kendilerini yalnz brrakıp gittig̈ine göre onlarn da Tököly'nin himayesine girmekten başka bir yapacaklan kalmadiğım yüksek sesle söylemekten çekinmiyorlard. Şehre given Garnizon ahaliyi vatana karşı ödevlerini başarmağa mecbur etmeseydi, eminim ki dediklerini yapacaklardi". ${ }^{110}$

Viyana'daki dehşet verici korku, kentte büyük bir kargaşa ve paniğe sebep olduğundan "Türkler kapılarda!" diye bağrişlıyordu. Çatışmalara dair gelen havadislerin tamamı doğru olmamasına rağmen halkın önemli bir bölümü, çok sayıda ve farklı dedikoduların tesiriyle daha da korkuya düşmüşlerdi. Insanlar en kısa sürede şehirden ayrılmak niyetindeydi. ${ }^{111}$ Zira güçlü ve hırslı Türklere duyulan korkunun hiçbir sınırı yoktu. ${ }^{112}$ Kara propaganda bağlamında bir araya getirilen çok sayıda klişe ve önyargı, Türkler hakkındaki ortak düşünme biçimini etkiledi. Kutsal Roma Imparatorluğu tarafindan ortaya atılan bu isnatlar yani Türklerin yakıp yıkan, her şeye gücü yeten bir tiranın görüntüsü olarak "Tann'nın kırbace" gibi olumsuz çağrışım uyandıracak birçok kavram broşürlerde, şïrlerde, şarkılarda veya askerî istihbaratlarda yer aldı. ${ }^{113}$

109 N. Karaçay Türkal, agt., s. 836; Mustafa Nuri Paşa, age., s. 282-283; Dimitri Kantemir, age., s. 47, 53; Johann W. Zinkeisen, age., s. 70; Ahmet Refik Altnnay, age., s. 31. Gevat Üstün, 1683 Viyana Seferi, s. 55; İsmail Hakkı Uzunçarşılı, age., s. 444.

110 Cevat Üstün, age., s. 54.

111 John Stoye, age., s. 186.

1121683 'te İngilizce okuma bilenlerin karşılaştıkları haberler dehşet vericiydi. Haberlerde, boyunlarına zincir vurularak saban süren üç Hristiyan'ın ve Tatarlar tarafindan atların peşinde sürüklenen insan tasvirlerinin meydana getirdiği korku had safhadaydı. Bu haberlere göre, bu yaşananlara Türkler sebep olmuştu; fakat bu, aynı zamanda Viyana hükümeti için de etkili bir kara propaganda ürünüydü. Andrew Wheatcroft, age, s. 118.

113 Stephan Theilig, "The Change of Imaging the Ottomans in the Context of the Turkish Wars 
Bu arada kale komutanı Starhemberg, Türklerle mücadele için halkın desteğini almak istiyordu. Dolayısıyla onları ikna etmek zorundaydı. Komutan halkı razı etmek için bir konuşma gerçekleştirdi. Konuşmasında Viyanalıları sakin olmaya davet etti ve memleketlerine destek vermelerini ögütleyen sözler sarf etti. İnsanları tahkimatlar üzerinde çalışmaya sevk eden Starhemberg, onları savunma için organize etmeye çalışarak Viyanalılarla birlikte yaşayıp, onlarla öleceğine dair söz verdi. ${ }^{114}$ Yine aynı gün Viyana Belediye Başkanı Von Liebenberg şehir meclisini toplantıya çağırdı. Onlardan gerek tahkimat sürecinde gerekse mühimmat tedarikinde yardımcı olabilecek insanlar talep etti. Fakat Leopold'un şehirden ayrılmış olması halk üzerinde ciddi bir isteksizliğe neden olmuş; bu nedenle insanlar savunma için yardım etmeye yanaşmamıştı. Hatta Von Liebenberg'in burjuva kesimini teşvik etmek için el arabasıyla kaleye toprak taşıması bile pek tesir etmemişti. Şehirdeki Türk korkusu halkın maneviyatını oldukça sarsmıştı. Starhemberg, Viyana halkının bu isteksizliği üzerine şiddete başvurmak durumunda kaldı. Şehirde kötü haber yayan kimseleri cezalandırarak halkın önemli bir kısmını bu yolla ikna etmeyi başard. ${ }^{115}$ Bundan sonra kuşatma başlamadan İmparator'un emrettiği hazırlıklar büyük ölçüde bitmiş, güneyde bir araya gelen kalabalık Türklere dair endişeler kısmen de olsa azalmıştı. ${ }^{16}$ Zira Türk ordusunun ağır yürüyüşüne karşılık zaman kazanan Viyanalılar haddinden fazla çalışarak 7 Temmuz'da kalede 10 top yerleştirebilecek yer yokken 13 Temmuz'da yaklaşık 300 topa yetecek kadar yatak meydana getirmişti. ${ }^{117}$

Yanıkkale'nin fethinden vazgeçen Kara Mustafa Paşa ordusuyla birlikte Viyana üzerine yürüyüşe devam etmekteydi. ${ }^{118} \mathrm{Bu}$ sırada Osmanlı ordusuna eşlik eden mehter takımı da gök gürlemesini hatırlatan ve insanlara korku veren marşlar çalıyordı. Öyle ki Sadrazam'ın tabyasında her koldan çalınan mehterden dolayı

from the 16th to 18th Century", Cahiers de la Méditerranée, 83, 2011, s. 1.

114 Henry Elliot Malden, Vienna 1683: the history and consequences of the defeat of the Turks before Vienna, September 12, 1683, by John Sobieski, King of Poland, and Charles Leopold, Duke of Lorraine, London: K. Paul, Trench, 1883, s. 51.

115 Cevat Üstün, age., s. 57-58.

116 Andrew Wheatcroft, age., s. 132.

117 Cevat Üstün, age., s. 58.

118 Yürüyüş esnasında büyük bir engelle karşılaşmayan Osmanlılar Yanıkkale önüne geldiklerinde âdet olduğu üzere kale komutanına teslim çağrısında bulunmuş, fakat Habsburglu kale komutanı önce Viyana'ya saldırılmasını teklif etmişti. Komutan, "Şayed Viyana dïsserse biz bu kaleyi de size kan dökülmeden teslim ederiz." sözleriyle Kara Mustafa Paşa'nın bu kalenin fethinden vazgeçmesini sağlamış ve Viyana'ya kıyasla bu kalenin önemsiz bir hale gelmesini sağlamıştı. Bk. Johann W. Zinkeisen, age,s., 67; Cevat Üstün, age., s. 49. 
yeryüzü ve göğün titrediği belirtilmekteydi. ${ }^{119}$ Mehter marşları sayesinde Osmanlı askerlerinin manevi açıdan kendilerini savaşa hazır hissetmesi sağlanıyordu. Diğer bir yönüyle, mehter, düşmana korku ve çaresizlik aşılayarak bir bakıma propaganda vazifesi görmekteydi. Nitekim mehterle manevi bakımdan beslenen Osmanlı askerleri "Allah Allah" gibi savaş haykırışlarıyla birbirilerini kışkırtarak etrafa korku saçıyordu. Mehterin dövüşs sesi müziğiyle birleşen bu haykırışlar, bir söylentiye göre Viyana'da develeri bile daha hızlı hareket ettirmekteydi. ${ }^{120}$ Bu bağlamda, askerlerin moralini üst düzeye çıkarmak ve düşmanın ruh halini etkileyerek dirençlerini kırmak için mehter de önemli bir propaganda aracı olarak kullanılmaktaydı.

İk başlarda Orta Macaristan'a düzenlenecek seferin hedefi artık kesin bir şekilde Viyana'ydı. Sadrazam Kara Mustafa Paşa'nın Viyana üzerine sefer düşüncesi o ana kadar önemli bir engelle karşılaşmad. ${ }^{121}$ Bununla birlikte Sadrazam'nn bu kararından Padişah'ın haberi yoktu. Ordusuyla Viyana'ya yönelen Sadrazam, o ana kadarki gelişmeleri içeren ve seferin Viyana'ya yönelik gerçekleşeceğini belirten bir raporu Telhîsî İsmail Ağa'yla birlikte IV. Mehmed'e yolladı. Padişah, raporu Belgrad'da Abaza Köşkü'nde teslim aldı. Sadrazam'ın bu kararı beklenmedik bir hareketti. Dolayısıyla Padişah, "Kasdımı Yanık ve Komaran kal'alan idi. Beç kal'ası dilde yokidi. Ne aceb paşa saygısızhk idïp, bu sevdâya dïşmürs. Hoş imdi, Hakk ta âlâ âsân getüre. Lâkin mukaddem bildireydi nzâ virmezdim." diyerek Sadrazam'ın bu hareketi karşısındaki şaşkınlığını ortaya koydu. ${ }^{122}$

\section{Viyana Kuşatması}

Bizzat seferde bulunan Teşrifatçıbaşı, 11 Temmuz'da Hainburg Palankası'nın ele geçtiğini belirterek o güne kadar zaptedilen kale ve palankaların 110'u bulduğunu kaydeder. Viyana'da oluşan manzarayı "Allah' in lütfuyla düşmanlarn kalpleri dehşet ve korkuyla doldu." şeklinde ifade eder. ${ }^{123}$

119 N. Karaçay Türkal, agt., s. 842.

120 Jouni Suistula-Vamik D. Volkan, https://werere.academia.edu/35818865/On_Propaganda-From_Religious_Knives, s. 74 .

121 Osmanlı birlikleri, büyük bir direnişle karşılaşmadan birçok kale ve palankayı ele geçirmişti. Bunlar içerisinde Osmanlıları meşgul eden Uyvar'ın kuşatılması oldu. Fakat Charles Lorraine'in birlikleri Uyvar önünde hezimete uğradı. Komutan Lorriane, kaleyi kuşatarak kısa sürede ele geçireceğini düşünmüşse de bu girişimi başarısızlıkla sonuçlandı. Daha ayrıntılı bilgi için bk. N. Karaçay Türkal, agt., s. 812-813; Dimitri Kantemir, age., s. 52-53.

122 N. Karaçay Türkal, agt., s. 829.

123 Mehtap Yilmaz, agt., s. 80. 
Belgrad'dan yola çıkan Osmanlı ordusu 14 Temmuz'da Viyana önlerinde göründü. ${ }^{124}$ Kaleden taburuna giderken esir düsşen bir Viyanalı, taburda dokuz bin ve kalede 15 bin asker olduğunu belirtmiş; İmparator'un ise kuşatmadan önce Lintz şehrine kaçtığını haber vermişti. ${ }^{125}$ Bundan sonra Sadrazam, bu tarz kuşatmalarda âdet haline gelen teslim çağrısında bulundu. Bu doğrultuda, kale komutanı Starhemberg'e hitaben bir mektup gönderildi. Mektupta, "Müslümanlığ kabul edin ve Padişahımızn himayesinde huzur içinde yaşayn! Tahut kaleyi teslim edin ve Hristiyan kalarak yine Padişahımizm himayesinde huzur içinde hayat sürün; kaleyi terk etmek isteyenler olursa eşyalarm yanlarna alarak gitmelerine müsaade edin! Fakat karşı koymaya kalkarsamz, o zaman ölïm, yağma ve esir olma hepinizin kaderi olacaktr!!” sözleri yer alıyordu. Sadrazam'ın bu teklifine, "İ̧̧⿻rüde baş olanlarmmz bu bâbda cevap verecek söz bulamadiklarnndan, bizim bir iki günden berï hayli âdemimiz kerlmağın elemimiz var iken, şimdi bu kâğıdnn cevâbr yokdur." denilerek yanıtsız bırakıldı. Bunun üzerine Kara Mustafa Paşa, "Vebâli boyunlarnna. İmdi hemân toplar kurulsun ve piyâde metrise girüp, kal'a dövülsün." diyerek çevresi her yönden sarılan şehrin kuşatmasını resmen başlatmış oldu. Bu arada komutan Starhemberg, bir gün önce kıymetli eşyaları taşınarak boşaltılan kenar mahallelerin ateşe verilmesini emretti. ${ }^{126}$

Kara Mustafa Paşa'nın emriyle siper kazma çalışmaları gerçekleştirildi ve kale surları da dövülmeye başlandı. Bu arada, İmparator’un Viyana'dan kaçtığı haberini getiren bazı casuslar Viyana'da herşeyin karıştı̆̆ına, şehir surlarının harap halde bulunduğuna, idare merkezinin ise güçsüz ve korkak olduğuna dikkat çektiler. Bununla birlikte silah ve erzak depolarının boşaldığını ve ahalinin önemli bir kısmının Türklerin korkusundan öldüğu bilgisini verdiler. Bu havadisler Sadrazam'a niyetini icra etmesi için daha çok cesaret vermişti. ${ }^{127}$ Bundan sonra, Viyana'nın durumu hakkında haberdar olan Sadrazam askerlerine lağımlar açılmasını emretti. Ayrıca Kara Mustafa Paşa, askerlerine iltifatlarda bulunuyor, onların gönlünü yapacak davranışlar sergiliyor ve yeri geldikçe akçeler dağıtıyordu. ${ }^{128}$ Böylelikle Sadrazam askerlerinin de kendisi gibi şevkle Viyana için çalışmasını arzu ediyordu.

124 N. Karaçay Türkal, agt., s. 835; Mehtap Yılmaz, agt., s. 82; Râşid Mehmed Efendi-Çelebizâde İsmâil Âsım Efendi, age., s. 245; Joseph von Hammer, Büyük Osmanl Tarihi, C 6, çev. Mümin Çevik-Erol Kılıç, Üçdal Neşriyat, İstanbul 1992, s. 371.

125 N. Karaçay Türkal, agt., s. 841.

126 Mehtap Yılmaz, agt., s. 83; N. Karaçay Türkal, agt., s. 836; Joseph von Hammer, age., s. 371; Johann W. Zinkeisen, age., s. 72; John Stoye, age., s. 204.

127 Dimitri Kantemir, age, s. 47.

128 Göker İnan, agt., s. 1395. 
Kuşatma tüm hızıyla devam ederken, Viyana sınırları içerisinde büyük bir kitlesel çalışma başlatıldı. Düzenli birliklere destek olmak için bazı birlikler kuruldu. Bunlar arasında öğrenciler, tüccar yanında ve depolarda çalışan kişiler ile saray birliklerinden ayrılmış rütbeli askerler bulunmaktaydı. Dindar kimseler, yankı uyandıran sesleriyle ibadete çağrıda bulunurken, askerler görev yerlerinde, kent soyluları sarayda, üniversite öğrencileri, tüccarlar ve işçiler ise vazifelerinin başında bulunmak zorundaydılar. ${ }^{129}$ Türklerin şehre ateş ettiği bir sırada bir şarapnel parçası Aziz Michael Kilisesi’nin yanına düştü ve iddiaya göre patlama zamanı gelmeden üç yaşında küçük bir çocuk korkusuzca koşarak onu söndürdü. Bundan sonra atılan fişeklerden biri kalabalığın içerisine düşerek bir kadının yaralanmasına sebep oldu, düşen parçaları toplamaya çalışan vatandaşlar bir rahibin ikna etmesiyle onları düşman üzerine geri yolladı. ${ }^{130}$ Kentte yaşanan bu tür hadiseler Viyana halkının Türklere karşı kendilerini savunmak adına ikna olduklarını ya da cesaretlendirilmeye çalışıldıklarını gösteren önemli örneklerdi.

Gün geçtikçe kuşatma bütün ağırlığını hissettiriyordu. Bu durum, ilerleyen günlerde de devam etti. Sobieski'nin 19 Temmuz'da Brandenburg elektörü F. William'a gönderdiği mektupta ortaya çıkan manzaradan şöyle bahsediliyordu: "Şimdi Osmanl öfkesi her yeri kasıp kavuruyor, saldınlar, heyhat! Hristiyan prensleri vuruluyor, kulıçan geçiriliyor...". ${ }^{131}$ Viyana Kumandanı Starhemberg tarafindan Lorraine’e gönderilen bir şifreli mektup ise Osmanlıların eline geçti. Kara Mustafa Paşa bu mektubu 26 Temmuz'da ek bir yazıyla birlikte bir okun ucunda Burg yarımay tabyasına firlatt1. Sadrazam gönderdiği mektupta kentin durumunu iyi bildiğini, teslim olmaları durumunda affedileceklerini belirtti. Bununla birlikte bir an tereddüt göstermeleri halinde herşeyin yakıp yakılarak insanların öldürüleceğine işaret etti. Ancak Starhemberg bu mektuba bir karşıllk vermedi. ${ }^{132}$

129 A fournal or a most particular account of all that passed in the late siege of Vienna, Rogers\&Gyllishower, London 1684, s. 26; Joseph von Hammer, age., s. 373. Bu gönüllü teşkilatın sayısı neredeyse 5000 civarındaydı. Bunlardan şehrin savunmasında faydalanılan öğrenci grubunun sayısı 700 civarındaydı. Starhemberg onları Schotten, Neutur ve Karntner tabyalarına yerleştirdi. Diğerleri ise şehrin asayişini sağlamak ve yangınları söndürmekle görevlendirildi. Cevat Üstün, 1683 Viyana Seferi, s. 59.

130 Augusta T. Drane, The Knights of st. Fohn: withthebattle of Lepantoand Siege of Vienna, Burnsand Lambert, London 1858, s. 250.

131 Brandenburg elektörünün Lehistan'a yardım için asker göndermesi zorunluluğu, Doğu Prusya’nın eski derebeylik sistemine göre Lehistan krallığına bağlı olduğu dönemden kalmıştı; bir antlaşma ile de teyit edilen bu durum 1657'de sona erdi. John Stoye, age, s. 274.

132 A Journal or a most particular account of all that passed in the late siege of Vienna, s. 19; Joseph von Hammer, age., s. 376-377; John Stoye, age., s. 248-249. 
Kentteki son durum, Avrupa'daki telaşı her geçen gün daha da artırmıştı. Viyana şehrinin dolayısıyla Hristiyanlığın düşmemesi için savaş masraflarına yapılan katkılar artmaya başladı. ${ }^{133}$ Türklere karşı Viyana'yı savunmak ve destek sağlamak üzere şehir halkını galeyana getiren Hristiyan din adamları oldukça etkili faaliyetlerde bulundular. Imparator'a ruhanî danışmanlık yapan Marco Avianno ${ }^{134}$ bu isimlerin başında gelmekteydi. İtalyan asıllı bu papaz vaiz olarak çalışıyor ve tövbe ettirme işini yürütüyordu. Şöhreti Alplerin kuzeyine dek ulaşmıştı. Halk nazarında kazandığı kutsiyet ve şöhretiyle tüm zor zamanlarda ordunun yanında oluyor, askerlere hangi nedenle savaştıklarını hatırlatarak onlara cesaret veriyordu. Kilisenin değerli bir üyesi olan Avianno, Viyanalıların kendisine şükretmek için şüphesiz bir nedeni olduğu önemli hizmetlerde bulunmuştu. ${ }^{135}$

Kuşatma sırasındaki faaliyetlerinden dolayı kilit role sahip isimlerden birisi de rahip Leopold Graf Kollonitsch'ti. Kentin kurtulması için oldukça fazla destek veriyor, yardım için evini hastane olarak kullanıyordu. Nitekim hastaneler yaralılarla olduğu kadar hastalarla da doluydu. Dolayısıyla evinde kadınlar, çocuklar, yaşlılarla sürekli ilgilenmek zorunda kalmıştı. Sürekli olarak insanlara cesaret veriyor, şehrin savunmasına büyük katkıda bulunuyordu. Yoğun çabaları sonucu adı kentte baş koruyucu olarak anılıyordu. Daha önce Kandiye kuşatmasında da Hristiyanlığı cesurca savunan Kollonitsch, Viyana kuşatmasındaki yoğun çabalarından dolayı insanlığın iyilik ruhu olarak kabul edilen Aziz Vincent de Paule olarak görülmekteydi. Hatta bir söylentiye göre, onun bu şöhreti Osmanlı karargâhına yayılmıştı ve bu faaliyetlerinden dolayı Kara Mustafa Paşa intikam almak için başını almaya yemin etmişti. ${ }^{136}$

Viyanalıların bu girişimlerine karşılık Osmanlı tarafinda da askerlere moral kazandırmak için girişimler sürüyordu. 16 Temmuz'da ordunun önemli isimlerinden Rumeli Beylerbeyi Hasan Paşa’nın, çadırına isabet eden bir top nedeniyle onun

133 İtalya'daki her kasabadan Viyana'ya gönüllü bağışlar gelmeye başladı. Roma'nın kardinalleri ise destek için maddi ve manevi desteklerini esirgemediler. Augusta T. Drane, age., s. 253-254.

134 İmparator Leopold ve Kral Sobieski arasında Papalık gibi çalışan Marco Avianno, 1631'de İtalya'da burjuva bir ailenin çocuğu olarak dünyaya geldi. Cizvitler tarafindan eğitildi. İslam'a karşı faaliyetlerde bulundu ve henüz genç yaştayken Girit'e gitmek istediyse de başarısız oldu. Amacı Kandiye kuşatmasında şehitliğe erişebilmekti. Dinî düşüncelerine uygun düşmesi nedeniyle Kapüçin tarikatına üye oldu. 1680'den itibaren ölüm tarihi olan 1699'a kadar İmparator'a hem siyasi hem de manevi anlamda rehberlik etti. Bk. Karl August Schimmer, age., s. 148-149; Thomas M. Barker, age, s. 229.

135 Karl August Schimmer, age., s. 137; Augusta T. Drane, age., s. 268; John Stoye, age, s. 87.

136 Henry Elliot Malden, age., s. 52;.Augusta T. Drane, age., s. 248, 253; Joseph von Hammer, age., s. 384. 
cennet bahçelerindeki çiçeklere karıştğ̆ yani şehit olduğu yazıyordu. Bu moral bozucu haber üzerine Sadrazam eldeki tutukluların öldürülmesini emrederek intikam almak istedi. Bu doğrultuda, 150 tutuklu Leylek Çadırı önünde öldürüldü. ${ }^{137}$

Ne var ki, bir savaşın kazanılmasında askerlerin morali önemli bir meseleydi. Birkaç gün sonra, 23 Temmuz'da Sadrazam metrisleri dolaşarak askerlere kazanma arzusu aşılamaya çalıştı. Yine topladığı ileri gelen devlet adamlarına kuşatma için gayret etmeleri gerektiğini belirtti. ${ }^{138}$ Ona katılan Teşrifatçıbaşı da "Allâh-u Te âlâ Hazretleri asker-i İslâm'a nusret ü kuvvet ve a dấ-i dîne kahr ü hezîmet müyesser eyleye, Amîn!'’139 şeklinde seslenerek Allah'a ve din düşmanlarına karşı zafer diliyordu.

Kuşatma süresi Ağustos’a sarkmış fakat kale henüz teslim olmamışt. ${ }^{140} \mathrm{Bu}$ arada yeniçeriler arasında şikâyetler başlamıştı. Zira Osmanlı askerlerine kaleye genel saldırı izni verilmemişti. Kaleye yapılan ufak saldırılar artık onları rahatsız etmişti. Yeniçeriler, bu küçük hücumların fayda etmediğini, tersine genel bir hücumla verilecek kaybın daha az olacağını haykırıyorlardı. Onlara göre bir kuşatma 40 günü geçmemeliydi. Dolayısıyla ferman verilmediği takdirde, metrislerini terk edeceklerini belirtmişlerdi. Askerler arasında yayılan şayiaların artması üzerine Sadrazam, Sultan'ın emrine karşı gelmek istemediğini belirtti. Bir iddiaya göre Kara Mustafa Paşa, kentte var olduğu düşünülen hazinenin yağma edilmesine izin vermek istemiyordu. Bu sebeple, kentin fethedilmesi halinde varsayllan bu hazineye el konulmaması için bir beyanname yayınladı. Bundan sonra kalenin vire ile teslim alınmasında karar kılındı. ${ }^{141}$ Gün geçtikçe kuşatma uzamaya devam ediyor, Sadrazam muhasaranın devam etmesi için propaganda faaliyetlerini sürdürüyordu. Mesela 25 Ağustos’ta metrisleri dolaşan Sadrazam, Deli Bekir Paşa, Yusuf Ağa, Hüseyin Paşa, Rodoslu Mustafa Paşa ve diğer kumandanları tabyasına getirtti. Hepsini tek tek uygun bir dille uyardı. Bu etkili ikazdan sonra, can ve mallarını İslam uğruna harcamalarını, kuşatmanın zaferle sonuçlanması için tüm güçlerini kullanmalarını emretti. Ardından kendi çadırına döndü. ${ }^{142}$

137 Mehtap Yılmaz, agt., s. 86-87; Râşid Mehmed Efendi-Çelebizâde İsmâil Âsım Efendi, age., s. 246; Nicolae Jorga, age., s. 170.

138 N. Karaçay Türkal, agt., s. 846.

139 Mehtap Yilmaz, agt., s. 118.

140 Kent düşmemişti ancak Tökeli İmre'den gelen haberlere göre, birçok yerden itaat haberleri gelmeye devam etmekteydi. Bk. N. Karaçay Türkal, agt., s. 855.

141 Dimitri Kantemir, age., s. 54; Uğur Demir, agt., s. 4-5.

142 Mehtap Yılmaz, agt., s. 111. John Stoye, age, s. 319. Bu arada Viyana önlerinde mücadele devam ederken imparatorluk kuvvetleri Pojon (Pressburg)'u kuşatan Tökeli İmre ve Kör Hüseyin 
Ne var ki, uzun süren yoğun çabalar karşısında en sağlam kuvvetler bile en sonunda bitkin düşmeye mahkûmdu. Altı hafta devam eden kuşatmadan sonra, yani Ağustos ayı bitiminde yaşanan güçlükler üst düzeye varmıştı. Viyana her an düşebilirdi. Kalede altı bin kişi ölmüş ve her gün salgın hastalıklardan ötürü ciddi güçlükler yaşanıyordu. Yiyecek, içecek ve mühimmat azalmıştı. 4 ile 6 Eylül'de iki büyük lağım patlatıldı. Artık şehrin direnmesi için olağanüstü çabalar gerekliydi. Ümitlerin tamamen tükendiği günlerde, uzun süredir hasretle beklenen yardım haberi kent halkına moral oldu. Nitekim 6 ila 9 Eylül tarihleri arasında Lorraine'in ordusu ile Lehistan Kralı Sobieski'nin yardımcı birlikleri Tulln Ovaları'nda bir araya geldi. ${ }^{143}$

Osmanlı tarafinda ise askerlerin savaşa istekli devam etmeleri için gayret ediliyordu. Bu uğurda Şeyh Vânî Mehmed Efendi de metrislerde dolaşarak savaş hattında bulunan Müslüman askerlere teşvik ve teselli edici şeyler söylüyordu. Konuşmalarında, Osmanlı birliklerine cihat ve şehadetin önemine dair ögütler veriyordu. Öyle ki bu çabalarıyla herkesin takdir ve hayranlığını kazanmıştı. ${ }^{144}$ Ancak kuşatmanın artık gereğinden fazla uzaması Osmanlı ordusundaki dengelerin sarsılmasına neden oldu. ${ }^{145}$ Kuşatmada yerlerini terk eden bazı Osmanlı askerleri oldu. Bu durum karşısında Kara Mustafa Paşa, Budin Beylerbeyi İbrahim Paşa'dan tavsiyede bulunmasını istedi. İbrahim Paşa kuşatmanın derhal kaldırılmasını ve düşman üzerine gidilmesini teklif etti. Hatta birkaç paşa dışında, diğer paşalar da Sadrazam'dan aynı talepte bulunarak Osmanlı Devleti'nin geri dönülemez bir hale düşmemesi için ricada bulundu. Ancak Sadrazam kuşatma fikrinden vazgeçmek istemedi. Paşalara, o ana kadar çekilen zahmetlerden söz etti. Ayrıca şehit düşen onca Osmanlı askerinin intikamı alınmadıktan sonra tam başarıya ulaşılabilecek bir sırada geri çekilmenin askerlerin cesaretini kıracağını ve bu nedenle istekli sa-

Paşa'nın birliklerine saldırmıştı. Tökeli'nin korkak davranması, dolayısıyla Paşan'ın güç duruma düşmesi üzerine Sadrazam'dan 10.000 asker desteği istendi. Kara Mustafa Paşa, hemen Kırım Hanı'nın oğlu Alp Giray komutasında istenen desteği gönderdi. Ancak yolda Tatar kuvvetlerinden ayrılanlar oldu, bu nedenle istenen destek kuvvetlerinin sayısı oldukça düştü. Bu arada imparatorluk kuvvetleri geri çekilmiş olduğundan Hüseyin Paşa, Alp Giray ve Tökeli İmre kuvvetleriyle Viyana'nın kuzeyine Stammersdorf'a geldiler. Fakat burada düşmanın üstün ordusu karşısında yenildiler. Bu arada Sadrazam, Tuna ötesine destek yollayamadığından Hüseyin Paşa az sayıdaki askeriyle kahramanca savaşırken şehit düştü. Bk. N. Karaçay Türkal, agt., s. 863-867; Halil İnalckk, age., s. 194-195.

143 Johann W. Zinkeisen, age., s. 73-74.

144 Mehtap Yllmaz, agt., s. 115; Joseph von Hammer, age., s. 378.

145 Ayrıntılı bilgi için bk. Cevat Üstün, age., s. 75. 
vaşmayacağını belirtti. Bu minvalde gerçekleşen müzakereden sonra kuşatma fikrinde 1 srarcı olan Sadrazam, paşaların fikrini geri çevirdi. ${ }^{146}$

Kırım Hanı tarafından Kara Mustafa Paşa'ya 35 bin kişilik bir Leh ordusunun Viyana'ya yaklaştı̆̆ı haber verildi. Daha önce de Sadrazam’ın kuşatma fikrine muhalefet eden Kırım Hanı Murad Giray bu konuda uyarıcı nitelikte sözler sarf etse de onun inadını kıramadı. Hatta Sadrazam Kırım Hanı'na gönderdiği haberde, "Gelecek imdâdı bilürüm, üç dört bin Lehlü ile beş on bin Nemçe, tevâtür idicek ne var." diyor ve Tatarlara hitaben şöyle devam ediyordu: "Hayda, onlar ne bilir, varsin beygirlerini gütsün. Ben gelen kâfiri çadır oğlanlarma tepeletirim. Onlarn korkulan varsa karı̧masınlar." Sadrazam kendinden oldukça emindi ve dolaşan söylentileri küçümsemeye kalkıştı. Bu gelişmelerden Kara Mustafa Paşa’nın acınacak haldeki din düşmanlarının eylemlerini göz ardı ettiği anlaşılıyordu. ${ }^{147}$

Müttefik kuvvetler 10 Eylül'de Kahlenberg'e doğru hareket etti ve 11 Eylül'de buraya vardı. Kalede büyük sıkıntılar baş göstermişti. Kale kumandanı Starhemberg imparatorluk ordularını komuta eden Lorraine'e hitaben, "Efendimiz, kaybedecek vakit yok; size yalvarmm, vakit kaybetmeyiniz." diyerek yardım diliyordu. Yardım isteği için havaya birçok fişekler firlatıldı. Buna karşılık, tepelerde dalgalanan sancaklar ve geceleyin atılan fişekler kente kurtuluşu müjdeliyordu. Bu arada Han tarafindan yakalanan esirlerden biri Sadrazam'a gönderilmişti. Gelen esir, Alman ve Leh ordularının birleştiğinden söz ederek, yaklaşık 80 bin piyade ve 40 bin süvari askerinin bir araya geldiğinden bahsetti. Bunun üzerine Kara Mustafa Paşa, kendilerine 12 Eylül'de hücum etmeyi planlayan müttefik kuvvetlere karş1, kendi birliklerine savaş düzenine geçmelerini ve her an hazır bir şekilde beklemelerini emretti. $^{148}$

Viyana, 12 Eylül Pazar günü savaşa hazırdı. Türklere karşı başarılı olmanın yolu güçlü bir propagandadan geçiyordu. Sabah askerlere ve halka savunma için teşvik edici sözler söylendi. Bu hususta gerek din adamları gerekse komutanlar oldukça ciddi hareket ettiler. Sabahın ilk 1şıklarıyla birlikte rahip Marco Avianno Leopoldsberd'de bulunan mihrapta kutsama törenini başlattı. Kilise ayini bittikten sonra

146 Kara Mustafa Paşa ile Budin Beylerbeyi İbrahim Paşa arasında gerçekleşen konuşma için bk. Dimitri Kantemir, age., s. 58-63; Göker Inan, agt., s. 1397-1398.

147 N. Karaçay Türkal, agt., s. 865; Mustafa Nuri Paşa, age., s. 283; Uğur Demir, agt., s. 5; Andrew Wheatcroft, age., s. 177.

148 N. Karaçay Türkal, agt., s. 876; Mehtap Yılmaz, agt., s. 119; Johann W. Zinkeisen, age., s. 73-74; Joseph von Hammer, age., s. 380. 
Avianno, rahip kıyafetleri içerisinde, elinde haç ile kilisenin kapısında duruyor, yüksek sesle, "Askerler, size ilan ediyorum, Kutsal Makam (Papalı) adına, Tann'ya güvenirseniz, zafer sizindir." "149 diyerek askerlere büyük bir moral veriyordu.

Bundan önce, Viyana’ya yürüyüş sırasında Leh ordusunun morali üst seviyedeydi, ancak iaşe sıkıntısından kaynaklanan birtakım hoşnutsuzluklar da ortaya çıkmıştı. Fakat Sobieski, bunun da üstesinden gelerek askerlerinin güvenini kazanmasını bildi. Cesaretlenen Leh askerleri heyecan ve gözyaşları içerisinde, "Kralımız Sobieski ile yaşayacă̆gz ve öleceğiz." diye bağırıyorlardı. ${ }^{150}$ Artık savaş günü gelmişti. Kral Sobieski de karşısında savaşmaya hazır ve hevesli bir güruh istiyordu. Bu nedenle, emrindeki askerlere geçmişteki zaferlerini anımsatarak şöyle seslendi:

“Savaşçlar ve yoldaşlar! Şu ovada bulunanlar düşmanlarımızdır. Hotin’de yendiğimiz düşmandan daha kalabalıklar. Onlarla yabancı bir toprakta savaşmak zorundayız, ancak kendi ülkemiz için savaşıyoruz ve Viyana duvarları altında Varşova ve Krakow’u savunuyoruz. Yalnızca bir şehri değil, aynı zamanda Hristiyanlığı kurtarmak zorundayız. Savaş kutsaldır. Üzerimizde bir lütuf ve ölenimiz için şeref tacı var. Sadece dünyevî iktidar için savaşmıyorsunuz aynı zamanda kralların kralı olan Tanrı için savaşıyorsunuz". ${ }^{151}$

Bundan sonra Sobieski askerlerine dönüp, "Tann ve Kutsal Anası bizimle!"152 diyerek birliklerini mücadeleye hazırladı.

12 Eylül günü Hristiyan kuvvetlerce genel bir taarruz başlatıldı. Düşmanlar dağa ulaştılar ve buraya yayıldılar. Savaşın görgü şahitlerinden Teşrifatçıbaşı, müttefik kuvvetlerin herşeyi ezip geçen ve yakan kara bir sel felaketine benzediğini kaydetmektedir. Habsburg ordusu, Osmanlı ordusu üzerine sağ ve sol kanattan saldırıya geçti. Sağ cenahı savunan İbrahim Paşa’nın kuvvetleri çabuk düştü ve geri çekildi. Şam Beylerbeyi Hüseyin Paşa komutasındaki sol cenah direniş gösterse de çok sürmedi. Bundan sonra merkezde Sobieski’nin hücumuna karşı kuvvetleri kırılmaya başlayan Kara Mustafa Paşa otağına kadar geri çekilmek zorunda kaldı. Burada, durumun vehametini anlayınca canı pahasına savaşmak istediyse de yanında bulunan Sipahiler Ağası Osman Ağa ve Amca Hasan Ağa’nın Sancak-1

149 Augusta T. Drane, age., s. 269; Joseph vonHammer, age., s. 380.

150 Augusta T. Drane, age., s. 265; Sabire Arık, agt., s. 149.

151 Karl August Schimmer, age., 1879, s. 138; Augusta T. Drane, age., s. 269-270; Janusz J. Tomiak, "A British Poet's Account of the Raising of the Siege of Vienna in 1683", The Polish Review, Vol. 11, No. 4 (Autumn, 1966), s. 66-67.

152 Augusta T. Drane, age., s. 270. 
Şerif'in düşman eline geçmesinin çok daha pahalıya mal olacağı yönündeki telkinleriyle karargâhı terk etmeye mecbur kaldı. Osmanlı ordusunun tüm top, tüfek ve mühimmatıyla birlikte çadırları düşman kuvvetlerin eline geçti. Sadrazam’ın tercümanı İskerletzade Mavrokordatos'un deyimiyle savaşın neticesi akşamüstü kesinlik kazandı. Illk başlarda savaşmak için geldiklerini haykıran Osmanlı askerleri bozgundan sonra yemeden ve içmeden uzun süre geri çekilmek zorunda kaldı. Öte yandan Hristiyan karargâhı sevinç çı̆̆lıklarıyla inlerken Viyana halkının yanısıra zafer haberini alan tüm Avrupa bu zaferi kutlamaya başladı. ${ }^{153}$

Kara Mustafa Paşa ve beraberindekiler 14 Eylül'de Yanık sahrasına geldiler. Sadrazam’ı buradaki köprüde Erdel Kralı Apafi Mihal karşıladı. Budin Valisi'nin herkesten önce kaçarak Yanıkkale’ye geldiğini bildirdi. Bunun üzerine, Sadrazam hezimetten sorumlu gördüklerine hesap sormak istedi. Bu sebeple, başta İbrahim Paşa'yı görüşme için çağırtmışsa da Budin Valisi hastalığını bahane ederek reddetti. Buna daha çok öfkelenen Sadrazam öyleyse arabayla gelmesini emredince İbrahim Paşa Sadrazam'ın huzuruna çıkmak zorunda kaldı. Öfkeli Sadrazam, İbrahim Paşa'ya ağır hakaretler ettikten sonra İbrahim Paşa'nın itirazlarına karşlık verilmedi ve idam edilmek üzere ölüm sehpasına yollandı. Kırım Hanı da İbrahim Paşa gibi bozgunun sorumlularından biri olarak görüldü. Nitekim Leh askerlerinin geçişine mani olma görevini yerine getirmemişti. Kırım Hanı başta Kara Mustafa Paşa'nın huzuruna çıkmaya niyetlenmişse de oğulları ve yanındakilerinin tesiriyle o da huzura çıkmayı reddetti. Bunun üzerine sinirlenen Sadrazam, Murad Giray'ı azlederek yerine Hacı Giray'ı Kırım Hanı olarak tayin etti. ${ }^{154}$

Viyana önünde yaşanan hezimetin kabahati, Sadrazam'a yükleniyordu. Hasan Esirî, Budin'e geçen Sadrazam için değersiz kimseler tarafindan kötü sözler söylendiğini ifade etmektedir. Hatta ona göre halk, Viyana seferini ağızlarından düşürmeyip, "Bu seferi açdllar da ortallk ş̧̈yle oldr ve böyle old.." diyerek yerli yersiz söylentiler çıarıyordu. Öyle ki seferde yer almayan kimselerin de devlete dil uzattıkları kaydedilmektedir. Ancak Hasan Esirî, bu beyhude sözlerden vazgeçilerek Padişah'ın ve devlet ricalinin suçlanmaması gerektiğini kaydetmektedir. ${ }^{155}$

153 N. Karaçay Türkal, agt., s. 879-880; Mehtap Yılmaz, agt., s. 121-122; Göker İnan, agt., s. 1401, 1402-1403; Mustafa Nuri Paşa, age., s. 283; Râşid Mehmed Efendi-Çelebizâde İsmâil Âsım Efendi, age., s. 248-250; Dimitri Kantemir, age., s. 64-65; Nicolae Jorga, age., s. 171-172; İsmail Hakk1 Uzunçarşıll, age., s. 452-453.

154 N. Karaçay Türkal, agt., s. 881-882, 891-892; Mehtap Yılmaz, agt., s. 123-124, 132-133, 138; Râşid Mehmed Efendi-Çelebizâde İsmâil Âsım Efendi, age., s. 252; Mustafa Nuri Paşa, age., s. 284; Dimitri Kantemir, age., 66.

155 Göker İnan, agt., s. 1383; 1385; 1404. 
Budin'e geçen Kara Mustafa Paşa buradan Padişah'a sefer ve akıbetiyle ilgili uzun uzadıya bir rapor yolladı. Bu raporda, kuşatmanın sonuna dek şehrin düşeceğinden ümitli olunduğu ancak bazı paşalar yüzünden harekâtın başarıya ulaşmadığını belirtmişti. Başta İbrahim Paşa ve diğger cezalandırılan paşaların tutumundan bahsetmiş ve kendisinin bu hezimette masum olduğuna dikkat çekmek istemişti. ${ }^{156}$ Sadrazam, 16 Ekim'de Budin'den ayrıldı. Bu tarihten üç gün önce Budin'i terk eden Padişah’a söz verdiği üzere, baharda giderlerini karşlayacağı ve elden çıkan bütün yerleri yeniden kazanacağı bir sefere hazırlık için Belgrad'a hareket etti. Daha sonra Sadrazam ve Osmanlı ordusundan geriye kalan kuvvetler herhangi bir engelle karşılaşmadan 17 Kasım'da Belgrad'a vardılar. Kara Mustafa Paşa, halktan hakikati gizlemek için Belgrad'a büyük bir zafer töreni ile girdi. Padişah ise, ilk başta Sadrazam'a karşı bir önlem almadı ve aynı tarihlerde önce Filibe'ye, ardından Edirne'ye geçti. ${ }^{157}$

Kara Mustafa Paşa, akıbeti konusunda herhangi bir sürprize mahal vermemek için IV. Mehmed'e raporlar göndermeye devam etmişti. Bu raporlar, kendisiyle beraber seferde bulunan bazı komutanlarla ilgiliydi. Zira bu subayların kendisi hakkında sarayı etkileyecek propaganda faaliyetlerinde bulunacağını düşünüyor, bu nedenle onların da suçlu olduğunu vurgulayarak diğer paşalar gibi onların da cezalandırılmasını istiyordu. Ancak korktuğu üzere, ordudan bazı askerler de saraydaki dostlarını gelişmelerden haberdar etmekten geri durmamışlardı. Bununla birlikte, baştan beri Sadrazam'a karşı olup onun başarıya ulaşmasını arzu etmeyen bazı saray mensupları da mevcuttu. Bunların başında Mirahur Süleyman Ağa ile Kızlarağası Yusuf Ağa gelmekteydi. Sadrazam'a kin tutan bu isimler kaymakam ve aynı zamanda Kara Mustafa Paşa'nın hamiliğini yaptığı Kara İbrahim Paşa'yı da etkileyerek kendi yanlarına çektiler. Bu saraylılar, Padişah'a sürekli Sadrazam'ın başarısızlığı ve cezasının verilmesi gerektiği konusunda telkinlerde bulundular. Başta bunların fikrine yanaşmayan IV. Mehmed, Sadrazam'a kılıç ve kaftan göndermişti. Fakat Kızlarağası Yusuf Ağa’nın ısrarlı telkinlerine dayanamayan IV. Mehmed, bir süre sonra Sadrazam'ın idamına karar verdi. Sadrazam’a karşı yürütülen karşı propagandalar artık sonuç vermişti. Sadrazam, Padişah'ın emrini götüren görevlilerce 25 Aralık 1683 'te Belgrad'da boğdurularak idam edildi. ${ }^{158} \mathrm{Bu}$

156 Dimitri Kantemir, age., s. 72-74.

157 Nicolae Jorga, age, s. 175.

158 N. Karaçay Türkal, agt., s. 911-915; Mehtap Yılmaz, agt., s. 169-170; Râşid Mehmed Efendi-Çelebizâde İsmâil Âsım Efendi, age., s. 257; Dimitri Kantemir, age., s. 76-78; Johann W. Zinkeisen, age., s. 78. 
tarihe kadar büyük bir hırsla Viyana'yı hedef alan ve propagandalarında büyük ölçüde başarılı olan Sadrazam’ın bozguna uğraması kendisine yönelik karşı propagandaların ortaya çıkmasına zemin hazırladı. Saraydakilerin karşı propagandaları onun sonunu hazırlamış oldu. Bu hezimetle birlikte Osmanlı Devleti'nin Avrupa topraklarından geri çekilişi de başladı.

Dönemin Venedik balyosu, Osmanlı ve Batı dünyası için dönüm noktalarından biri olan bu seferi şu sözlerle özetlemektedir: "Böylece büyük bir görkem, büyük çabalar ve zenginlik ve itibar umudu ile başlatılan bu savaş, büyük kaynlar, utançlar ve ölüm ile sonuçlandi". ${ }^{159}$ Gerçekten de bu hezimetten sonra yenilmez addedilen Türkler, artık korku unsuru olmaktan çıkmaya başladı. Bu durum, aynı zamanda Türklere karşı propagandanın yöntemlerini de değiştirdi. Nitekim korkulan Türk imajının değişmesiyle, Hristiyan halka Türk korkusunu aşılamada başı çeken Kilise'nin de bundan sonraki propaganda faaliyetleri sinırlandı. Bununla birlikte Kilise'nin insanların zihnine yerleştirdiği "kötü Türk" imgesi uzun bir dönem hafizalardan silinemedi. ${ }^{160}$

Hasan Esirî’nin kaydettiğine göre, Viyanalılar, kendileri adına zafer Türkler için bozgun sayılan bu seferle ilgili eserler kaleme almış ve kış gecelerinde okurlarmış. Hatta kendi okuduğu bir eserde, Hz. Âdem'den bu yana böyle bir hadisenin yaşanmadığı gibi abartılı bir kaydın bulunduğunu ifade etmektedir. Yine o da bu seferin Viyanalılar üzerindeki tesirini "... ammâ ol seferde vilâyetlerine olan hakāret dahi kıyâmete değin derûnlarından çıkmayup mûcib-i ibret olmağla..." sözleriyle ifade etmiştir. ${ }^{161}$

\section{Sonuç}

Propaganda, harp tarihi göz önüne alındığında, savaş kararlarının alınmasından bu savaşların sonuçlanmasına kadar süren süreçte karar mekanizmalarına yön veren önemli bir araç olmuştur. Zira insanların ruh hallerine tesir eden propaganda, kitleleri bir amaç uğrunda etkileyerek ve ikna ederek hedefe ulaşmada önemli bir role sahiptir. Bu çerçevede, insanların zihninde savaşı kazanma güdüsünün aşılanması hayatî öneme sahip olmuştur.

1683 Viyana Kuşatması, güçlü bir propagandayla, insanları zihinsel açıdan et-

159 Nicolae Jorga, age, s. 157.

160 Mustafa Çolak, "XVI. Ve XVII. Yüzyıllarda Orta Avrupa'da Türk İmajı ve II. Viyana Kuşatması ile Kazandığı Boyut", Merzifonlu Kara Mustafa Paşa Uluslararası Sempozyumu (08-11 Haziran 2000), Yay. Haz. Zeki Dilek vd., Ankara 2001, s. 270.

161 Göker İnan, agt., s. 1407. 
kilemenin hedefe ulaşmada ne denli etkili olduğunu gösteren tipik bir örnektir. Cesur, hırslı ve disiplinli bir sadrazam olan Kara Mustafa Paşa'nın yoğun propaganda çabalarının daha çok seferin meşruiyetini sağlama ve insanları bu savaşa hazırlama odaklı olduğu görülmektedir. Kuşatmanın son bölümlerine kadar Kara Mustafa Paşa, çeşitli yollarla kitleleri rahatlıkla ikna edebilme kabiliyetine sahip biri izlenimi vermektedir. Bunu yaparken yaygın bir şekilde sözlü ve yazılı iletişim yöntemlerinden faydalanmıştır. İnsan gücü seferberliğinde oldukça başarılı bir görüntü sergilemiştir. Ancak Sadrazam'ın büyük propaganda girişimleri neticesinde verilen sefer kararı ve ardından uğranılan hezimet bu defa Osmanlı sarayında ona karşı yapılan anti-propaganda faaliyetlerinin fitilini ateşlemiş; hatta saraydakilerin bu girişimleri onun idam edilmesine sebep olmuştur.

Türklere karşı savaş istemeyen, ancak harbin eşiğine gelen Habsburg hükümeti gerekli olan maddi ve manevi destek için yurt içinde ve yurt dışında önemli propaganda girişimlerinde bulunmuştur. Bu propaganda çalışmalarının ana teması Viyana'yı, dolayısıyla Hristiyanlığı Türklere karşı korumak olmuştur. Halkın mücadelesi olarak nitelendirebileceğimiz bir kitlesel seferberlik tesis etmiştir. Bunun için de Türkler hakkında ortaya atılan rivayetlerin çoğu dinî duyguları harekete geçiren bir hüviyette olmuştur. Büyük bir görkemle başlatılan bu kuşatmada, gözle görülür maddi olanakların manevi gücün gerisinde kalması bunu yansıtmaktadır. İnsanların zihinlerine işlenen propaganda faaliyetleriyle dinî duygular ağır basmış, kentin savunması için büyük fedakârlıklar yapılmıştır. Bu açıdan bakıldığında, siyaset ve din ilişkisinin iyi bir propagandayla nasıl bir boyuta ulaştığı dikkate değerdir.

Habsburg hükümetinin propaganda faaliyetlerinin sıradan olmadığını söylemek elbette mümkündür. Zira Türklere karşı mücadeleyi sürdürebilmek için hem manevi hem de finansal açıdan yaygın bir propaganda sürecine girilmiştir. Bilhassa insanların manevi dünyasına hitap edilmesinde Papalık yani Katolik Kilisesi üyelerinin destekleri su götürmez bir gerçektir. Kilisenin büyük propaganda girişimleri sonucu bu kuşatmaya olan destek sınırötesine taşınmışır. Katolik dünyasından Viyana'ya destek kampanyası yönündeki Papalık mektupları Türklere karşı bir savaş daveti niteliğindedir. Zira bu mektuplarla, Hristiyan âlemi Türklere karşı ayağa kaldırılmak istenmiştir. Ayrıca söz konusu dönemde egemen olan Türk imgesini göstermesi bakımından bu mektuplar ayrı bir öneme sahiptir. Başta bu mektuplar olmak üzere, dönemin basılı ve sözlü kaynaklarında Türkler tamamıyla insanlık dışı faaliyetlerde bulunan zalim bir topluluk olarak gösterilmiştir. Ayrıca kuşat- 
ma boyunca Habsburgların basılı yayın organlarıla yoğun propaganda yapması Avusturya'da yazıya dayalı kültürün geliştiğini de göstermektedir.

Kuşatmaya giden süreçte uygulanan propagandalara bakıldığında, savaşın başından itibaren Habsburg hükümeti Kilise kanalını kullanarak Hristiyan dünyasından yardım beklemiştir. Din eksenli yürütülen bu propaganda çalışmalarına en büyük desteğin Lehistan Kralı Jan Sobieski'den geldiği dikkat çekmektedir. Bunun yanında imparatorluğa bağlı bazı prensliklerden de önemli destek alınmıştır.

Osmanlı cephesinde kuşatmanın başından itibaren etkili bir propaganda süreci yürütülmüş olsa da ilerleyen süreçte komutanlar arasındaki ihtilaflar bu sürecin zedelenmesine neden olmuştur. Dolayısıyla başarıyla sonuçlanması beklenen bu kuşatma girişimi Osmanlı Devleti'nin aleyhine sonuçlanmıştır.

Avrupa tarihi için önemli bir dönüm noktası olan 1683 Viyana Kuşatması'nda sefere karar sürecinde, sahada ve cephe gerisinde genel olarak yazılı ve sözlü kaynaklar propaganda aracı olarak kullanılmıştır. Söz konusu dönemde, diplomatik kayıtlar, gazete, broşür gibi basın organları ve çağdaş kaynaklarda propaganda sayılabilecek çok sayıda ürün mevcuttur. Kuşatmada yer alan ruhban sinıfı ve devlet adamlarının hutbe, vaaz ve nutukları da sözlü propaganda yönteminin önemli bir parçası olmuştur. Tüm bu kaynaklardan hareketle, savaşın yalnızca cephede gerçekleşmediği açık bir şekilde görülmektedir. Nitekim savaş açanla buna maruz kalanlar arasında -savaş evresine gelinceye dek- hedef kitleler maddi ve manevi bakımdan savaşa hazırlanmaya çalışılmıştır. Öyle ki bu kuşatmada zafer elde eden tarafin maddi güç kadar manevi ruh hali de mücadelenin gidişatını ciddi derecede etkilemiştir. Sonuç olarak büyük propaganda kampanyaları yürütülen bu mücadele sonuçları itibariyle yeni gelişmelere ortam hazırlamıştır. Nitekim gelinen noktada, Osmanlıların Viyana önlerinde yenilgiye uğraması yenilmez Türk imajını büyük ölçüde sarsmıştır. 


\section{KAYNAKLAR}

A Journal or a most particular account of all that passed in the late siege of Vienna, Rogers\&Gyllishower, London 1684.

Abdurrahman İsa Efendi, 'İsâ-zâde Târîhi, haz. Ziya Yilmazer, İstanbul Fetih Cemiyeti, İstanbul 1996.

Aktepe, Münir, "Mustafa Paşa, Merzifonlu, Kara", İslam Ansiklopedisi, G 8, Milli Eğitim Basımevi, İstanbul 1979.

Altınay, Ahmet Refik, Osmanlı'nın Felaket Seneleri (1683-1699), 2. Baskı, Haz. Muammer Yılmaz, İlgi Kültür Sanat Yayıncılık, İstanbul 2017.

Arık, Sabire, Polonya Kralı III. Jan Sobieski ve Hükümdarlığında Osmanlı Lehistan İlişkileri (1674-1696), YDT, Ankara Üniversitesi Sosyal Bilimler Enstitüsü, Ankara 2004.

Ateş, Şeref, "Bir Siyasal İletişim Tarzı Olan Propagandanın Tanınması ve Propaganda Metinlerinin Çözümlenmesi”, Bilig, S. 13, (Bahar 2000), s. 117-131.

Ayhan, Ahmet, Propaganda Nedir?, L-T Literatürk Yayınları, İstanbul 2007.

Barker, Thomas M., Double Eagle and Crescent: Vienna's Second Turkish Siege and Its Historical Setting, Albany, New York: State University of New York Press, 1967.

Bektaş, Arsev, Kamuoyu, İletişim ve Demokrasi, Bağlam Yayınları, İstanbul 2000.

Bektaş, Arsev, Siyasal Propaganda Tarihsel Evrimi ve Demokratik Toplumdaki Uygulamalan, Bağlam Yayınları, İstanbul 2002.

Brzeziński, Szymon, "Forms And Functions of the Image of Hungary in Poland-Lithuania", in A Divided Hungary in Europe: Exchanges, Networks and Represantations, 1541-1699, Vol. III, ed. Gábor Almási, Szymon Brzezinski, Ildikó Horn, Kees Teszelszky, Áron Zarnóczki, Cambridge Scholars Publishing, 2014, s. 61-88.

Bon, Gustave Le, Kitleler Psikolojisi, çev. Hasan Can, Tutku Yayınları, Ankara 2014.

Brown, J. A. C., Siyasal Propaganda, çev. Yusuf Yazar, Ağaç Yayıncılık, İstanbul 1992.

Cull, Nicholas J. ve diğerleri, Propaganda and Mass Persuasion: a Historical Encyclopedia, 1500 to the Presents, New York: ABC-Clio, 2003. 
Çolak, Mustafa, "XVI. Ve XVII. Yüzyıllarda Orta Avrupa'da Türk İmajı ve II. Viyana Kuşatması ile Kazandığı Boyut", Merzifonlu Kara Mustafa Paşa Uluslararast Sempozyumu (08-11 Haziran 2000), Yay. Haz. Zeki Dilek vd., Ankara 2001, s. 265-272.

Danışman, Zuhuri, Osmanl İmparatorluğu Tarihi, C X, Yeni Matbaa, İstanbul 1965.

De La Croix, An account of the Turks wars with Poland, Muscory, and Hungary, çev. A. Chaves, London 1711.

Defterdar Sarı Mehmed Paşa, Zübde-i Vekayiât, haz. Abdülkadir Özcan, Türk Tarih Kurumu Yayınları, 1985.

Demir, Uğur, Târîh-i Mehmed Giray, YYLT, Marmara Üniversitesi Türkiyat Araşttrmalar Enstitïsü, İstanbul 2006.

Domenach, J. M., Politika ve Propaganda, çev. Tahsin Yücel, Varlık Yayınları, İstanbul 1969.

Domenach, J. M., Siyasi Propaganda, çev. Cevdet Perin, Yükselen Matbaası, İstanbul 1961 .

Drane, Augusta T., The Knights of st. Fohn: with the battle of Lepanto and Siege of Vienna, Burns and Lambert, London 1858.

Edhem, Halil, "Kara Mustafa Paşa'nın Şopron Şehri Ahalisine Beyannâmesi", TOEM, III/15 (1328/1912), s. 924-937.

Erdoğan, Meryem Kaçan, II. Viyana Kuşatması, YDT, Marmara Üniversitesi Türkiyat Araştırmalan Enstitiisü, İstanbul 2001.

Etényi, Nóra G., "The Genesis And Metamorphosis Of Images Of Hungary in The Holy Roman Empire", in A Divided Hungary in Europe: Exchanges, Networks and Represantations, 1541-1699, Vol. III, ed. Gábor Almási, Szymon Brzezinski, Ildikó Horn, Kees Teszelszky, Áron Zarnóczki, Cambridge Scholars Publishing, 2014, s. 15-43.

Faroqhi, Suraiya, Yeni Bir Hükümdar Aynası: Osmanh Padişahlarmn Kamusal İmgesi ve Bu İmgenin Alg̨lanması, çev. Gül Çağalı Güven, Alfa Yayınları, İstanbul 2011.

Fichter, Joseph H., Sosyoloji Nedir?, çev. Nilgün Çelebi, Anı Yayıncılık, Ankara 2001.

Geçikli, Fatma, "Geçmişten Günümüze Propaganda Kavramı", İstanbul Üniversitesi İletişim Fakültesi Dergisi, S. 9, 1999, s. 265-276. 
Gözübüyük, Sevil, "Osmanlı-Fransa Illişkilerinde Diplomatik Protokol Unsuru Olarak "İskemle" (XVI.-XVII. Yüzyllar)", ASEAD, C 5, S. 6, 2018, s. 98117.

Guilleragues Kontu, İstanbul Mektuplan, çev. Yaşar Avunç, Kırmızı Yayınları, İstanbul 2010.

Güvenç, Bozkurt, Türk Kimlïgi: Kültür Tarihinin Kaynaklar, 3. Basım, Remzi Kitabevi, İstanbul 1995.

Haffemayer, Stéphane, "Public and Secret Networks of News: The Declaration of War of the Turks against the Empire in 1683", in the Newes Networks in Early Modern Europe, Ed. Joad Raymond, Noah Moxham, Brill, Leiden\&Boston 2016, s. 805-823.

Hammer, Joseph von, Büyük Osmanh Tarihi, C 6, çev. Mümin Çevik-Erol Kılıç, Üçdal Neşriyat, İstanbul 1992.

İnalckk, Halil, Devlet-i Aliyye, Osmanl İmparatorluğu Üzerine Araştırmalar-III, Türkiye İş Bankası Kültür Yayınları, İstanbul 2015.

İnan, Göker, Hasan Esîrînin Mi‘yârü'd-Düvel ve Misbârü’l-Milel İsimli Tarih ve Coğrafya Eseri (İnceleme-transkripsiyon), YDT, Marmara Üniversitesi Türkiyat Araştrrmalar Enstitïiü, İstanbul 2017.

Jorga, Nicolae, Osmanh Imparatorluğu Tarihi (1640-1774), G 4, çev. Nilüfer Epçeli, Yeditepe Yayınları, İstanbul 2009.

Jowett, Garth S. And O'Donnel, Victoria, Propaganda and Persuasion, Sixth Edition, Sage Publications, USA 2015.

Kantemir, Dimitri, Osmanlı Imparatorluğunun Yükseliş ve Çöküş Tarihi, G 3, çev. Özdemir Çobanoğlu, Kültür Bakanlığı Yayınları, Ankara 1980.

Kotus, Karolina Anna, Polonyalı Elçi Jan Gniński'nin Türkiye Seyahatnamesi’ne Göre Osmanlı Ülkesi ve Osmanlılar (1677-1679), YYLT, Hacettepe Üniversitesi Türkiyat Araştırmalarn Enstituisü, Ankara 2015.

Kurat, Akdes Nimet, Rusya Tarihi Başlangļ̧tan 1917’ye Kadar, 6. Bask1, Türk Tarih Kurumu Yayınları, Ankara 2014.

Küçükoğlu, Bayram, Milli Mücadeleden Günümüze Silahsız Terör Propaganda, IQ Kültür Sanat Yayıncılık, İstanbul 2006. 
Malden, Henry Elliot, Vienna 1683: the history and consequences of the defeat of the Turks before Vienna, September 12, 1683, by John Sobieski, King of Poland, and Charles Leopold, Duke of Lorraine, London: K. Paul, Trench, 1883.

Molnár, Antal, "Relations between the Holy See and Hungary during the Ottoman Domination of the Country", in Fight Against the Turk in Central Europe in the First Half of the 16th Century, ed. István Zombori, Budapest 2004, s. 191226.

Mustafa Nuri Paşa, Netayicül-Vukuat, Kurumlarn ve Örgütleriyle Osmanl Tarihi, G I-II, sad. Neşet Çă̆atay, Türk Tarih Kurumu Yayınları, Ankara 1987.

Osmanzâde Taib Ahmed, Hadikatü'l-Vüzerâ, haz. D. Robischon, Freiburg 1969.

Özcan, Abdülkadir, "Viyana Bozgunun Maddi ve Manevi Sebepleri Dönemin Kısa Panoraması", Merzifonlu Kara Mustafa Paşa Uluslararası Sempozyumu (Merzifon-Amasya, 8-11 Haziran 2000), Ankara 2001, s. 229-239.

Özkan, Selim Hilmi, "XVII. Yüzyılın Sonlarında Hıristiyan Birliği Projesi ve Osmanlı-Fransız Ilişkileri”, SDÜ Fen Edebiyat Fakültesi Sosyal Bilimler Dergisi, Mayıs 2009, Say1:19, s. 61-72.

Özsoy, Osman, Propaganda ve Kamuoyu Oluşturma, Alfa Yayınları, İstanbul 1998.

Qualter, Terence H., "Propaganda Teorisi ve Propagandanın Gelişimi”, çev. Ünsal Oskay, Ankara Üniversitesi Siyasal Bilgiler Fakültesi Dergisi, C 35, S. 1, Ankara 1980, s. 255-307.

Palmer, Alan, Osmanl Imparatorluğu Son Üç Yüz Yıl Bir Çöküşün Yeni Tarihi, (Çev. B. Çorakçı Dişbudak), Sabah Kitapları, İstanbul, 1992.

Râşid Mehmed Efendi-Çelebizâde İsmâil Âsım Efendi, Târîh-i Râşid ve Zeyli, haz. Abdülkadir Özcan ve diğerleri, C I, Klasik Yayınları, İstanbul 2013.

Sauer, Augustin, Rom Und Wien Im Jahre 1683: Ausgewählte Actenstücke Aus Römischen Archiven Zur II. Säcularfeier Der Befreiung Wiens Als Festgabe Des Unter Allerhöchstem Protectorate Stehenden Priestercollegiums Von Campo Santo Zu Rom, K. K. Hof- und Staatsdruckrei, Wien 1883.

Schimmer, Karl August, The Sieges of Vienna by the Turks, translated from the Germany by the Earl of Ellesmere, John Murray, London 1879.

Severin, Werner J.-Tankard, Jr., James W., Iletişim Kuramlar, çev. Ali Atıf Bir-Serdar Sever, Eskişehir: Anadolu Üniversitesi Yayınları, 1994. 
Stoye, John, İkinci Viyana Kuşatması, Çev. Selahattin Atalay, Dilek Matbaası, İstanbul 1984.

Suistula, Jouni-Volkan,Vamik D., https://wrereacademia.edu/35818865/On_Propaganda-From_Religious_Knives, s. 74.

Süreyya, Mehmed, Sicill-i Osmanî, G IV, haz. Nuri Akbayar, Tarih Vakfi Yurt Yayınları, İstanbul 1996.

Tarhan, Nevzat, Psikolojik Savaş, Timaş Yayınları, İstanbul 2006.

Tatlock, Lynne, "Selling Turks: Eberhard Werner Happel's Turcica (16831690)", Colloquia Germanica, Vol. 28, No. $3 / 4$ (1995), s. 307-335.

Taylor, Philip M., Munitions of the Mind, A history of propaganda from the ancient World to the present era, Third Edition, Mancher University Press, Manchester 2003.

Tekinsoy, Yunus Emre, "Birinci Balkan Savaşı'nda Bir Propaganda Unsuru Olarak Vaaz”, Sosyal Bilimler Araştırmalan Dergisi (SBAD), Kış 2018, 13/2, s. 317-341.

Stephan Theilig, "The Change of Imaging the Ottomans in the Context of the Turkish Wars from the 16th to 18th Century", Cahiers de la Méditerranée, 83, 2011, s. 1-10.

Tomenendal, Kerstin, “I. Dünya Savaşı'nda Avusturya-Macaristan ve Osmanlı Devletleri Arasındaki Bağlantının Farklı Bir Yönü: Avusturya Menşeli Propaganda Kartpostalları", XIV. Türk Tarih Kongresi, 09-13 Eylül 2002, II. Cilt, II. Kısım, Ankara 2005, s. 1317-1338.

Tomiak, Janusz J., "A British Poet's Account of the Raising of the Siege of Vienna in 1683", The Polish Review, Vol. 11, No. 4 (Autumn, 1966), s. 66-74.

Türk Dil Kurumu, Güncel Türkçe Sözlük, "Propaganda", Erişim Tarihi: 19.02.2019, 20:18, http://www.tdk.gov.tr/index.php?option=com_gts\&arama=gts\&guid=TDK.GTS.5c6c3648c12975.22398672.

Türkal, N. Karaçay, Silahdar Fındıklılı Mehmed Ağa, Zeyl-i Fezleke (1065-22 Ca.1106/1654-7 Şubat 1695) Tahlil ve Metin, YDT, Marmara Üniversitesi Türkiyat Araştırmalan Enstitüsü, İstanbul 2012.

Uzunçarşılı, İsmail Hakkı, Osmanl Tarihi, II. Selim’in Tahta Çıkışından 1699 Karlof̧ca Andlasmasına Kadar, C III, 6. Baskı, Türk Tarih Kurumu Yayınları, Ankara 1988. 
Üstün, Gevat, 1683 Viyana Seferi, 2. Baskı, Türk Tarih Kurumu Yayınları, Ankara 2010.

Vocelka, Karl, "Erken Yeniçağda Hristiyan Batı Dünyasında Türk İmajı", çev. Songül Çolak-Fatma Akay-Türker, Gaziosmanpaşa Üniversitesi Sosyal Bilimler Araştırmalan Dergisi, 11/2, (Kış 2016), s. 247-267.

Walton, Douglas, "What is Propaganda, and What Exactly is Wrong with It" Public Affairs Quarterly, Vol. 11, No. 4 (Oct., 1997), s. 383-413.

Wheatcroft, Andrew, Kapidaki Düsman, Habsburglar ile Osmanllarn Avrupa Mücadelesi, çev. Neşenur Domaniç, Doğan Kitap, İstanbul 2012.

Yılmaz, Mehtap, Vekâyi'-i Beç, YYLT, Marmara Üniversitesi, Türkiyat Araştırmalan Enstitiusü, İstanbul 2006.

Yllmaz, Yasir, The Road to Vienna: Habsburg and Ottoman Statecraft During the Time of Kara Mustafa Paşa (1676-1683), PhD Disserttion, Purdue University, Indiana 2015.

Zinkeisen, Johann W., Osmanh İmparatorluğu Tarihi, C 5, çev. Nilüfer Epçeli, Yeditepe Yayınevi, İstanbul 2011. 
